\title{
Incorporating life-cycle external cost in optimization of the electricity generation mix
}

\author{
Athanasios Rentizelas ${ }^{1 \dagger}$, Dimitrios Georgakellos ${ }^{2 *}$ \\ ${ }^{1}$ University of Strathclyde, Design Manufacture and Engineering Management Dpt. \\ 75 Montrose str., G1 1XJ, Glasgow, UK \\ ${ }^{2}$ University of Piraeus, Department of Business Administration \\ Karaoli \& Dimitriou 80, 18534 Piraeus, Greece
}

\begin{abstract}
The present work aims to examine the strategic decision of future electricity generation mix considering, together with all other factors, the effect of the external cost associated with the available power generation technology options, not only during their operation but also during their whole life-cycle. The analysis has been performed by integrating the Life Cycle Assessment concept into a linear programming model for the yearly decisions on which option should be used to minimise the electricity generation cost. The model has been applied for the case of Greece for the years 2012-2050 and has led to several interesting results. Firstly, most of the new generating capacity should be renewable (mostly biomass and wind), while natural gas is usually the only conventional fuel technology chosen. If externalities are considered, wind energy increases its share and hydro-power replaces significant amounts of biomass-generated energy. Furthermore, a sensitivity analysis has been performed. One of the most important findings is that natural gas increases its contribution when externalities are increased. Summing-up, external cost has been found to be a significant percentage of the total electricity generation cost for some energy sources, therefore significantly changing the ranking order of cost-competitiveness for the energy sources examined.
\end{abstract}

Keywords: Electricity generation mix; Life cycle assessment; Externalities.

\footnotetext{
${ }^{\dagger}$ Corresponding author: Tel.: +30-210-7722383; fax: +30-210-7723571. E-mail address:

athanasios.rentizelas@strath.ac.uk

"Tel.: +30-210-4142252; fax: +30-210-4142339. E-mail address: dgeorg@unipi.gr
} 


\section{INTRODUCTION}

When comparing environmental issues of different options fulfilling a similar function, it is important to consider the complete life cycle and not only one phase, e.g. production or use. This is because environmental impacts and benefits may occur at different phases of the life cycle. The most important phases may not be the same when two options are compared (Moberg et al., 2005). Thus, a life cycle approach is needed and, more precisely, the Life Cycle Assessment (LCA) methodology should be used. LCA is a method for evaluating the environmental impact associated with a product, process or activity during its life cycle by identifying and describing, both quantitatively and qualitatively, its requirement for energy and materials, as well as the emissions and waste released to the environment (Madival et al., 2009; Liu et al., 2010).

Nowadays, many companies have been practicing environmentally conscious design and manufacturing to tackle environmental issues by LCA (Zutshi and Sohal, 2004; Nakano and Hirao, 2011). Moreover, the use of LCA in environmental management and sustainability has grown in recent years as evidenced by the steadily increasing number of published papers and case studies on LCA methodology (Notarnicola et al., 2012). As a result, life cycle management is quickly becoming a well-known and often used approach for environmental management in the energy sector as well. Thus, LCA studies of different energy products (Von Blottnitz and Curran, 2007), fuels (Dinca et al., 2007; Tsoutsos et al., 2010), power generation systems (Babbitt and Lindner, 2005; Georgakellos, 2012) and relevant technologies' appraisals (Nguyen and Gheewala, 2008) are very common. 
On the other hand, the LCA framework seems to be, to some extent, ignored in electricity demand forecasting and in power generation technologies' mix projections. Specifically, there is a noteworthy number of such studies in the literature attempting to investigate future electricity generation of particular countries, such as India (Grover and Chandra, 2006), Kazakhstan (Atakhanova and Howie, 2007) and Turkey (Kucukali and Baris, 2010). Similarly, Lady (2010) demonstrated the basic feasibility of approximating some portions of the US National Energy Modeling System projections for the amounts of electricity and natural gas consumed by the residential and commercial sectors with linear regression results. Among these studies, only few consider in their projection the environmental impact of the examined scenarios, primarily focusing on the climate change as a result of $\mathrm{CO}_{2}$ emissions. For example, Rachmatullah et al. (2007) presented a scenario planning for the electricity generation in Indonesia, Dilaver and Hunt (2011) modelled and forecasted the Turkish residential electricity demand and Simshauser et al. (2007) analysed the economic and environmental impact of various future electricity generation technology options in Australia. In addition, Rentizelas et al. (2012) investigated the effect that various scenarios for emission allowance price evolution may have on the future electricity generation mix of Greece. Only Liu et al. (2011) include the carbon dioxide life cycle emissions in their analysis, which concerns a preliminary prediction of the development of renewable energy in China for the future decades.

Thus, the present work is, to the best of our knowledge, the first research attempting to investigate whether and how the strategic decision of future electricity generation mix may be affected by the external cost associated with the 
available electricity production technology options, not only regarding their operation but also considering their whole life-cycle. This is based on an appropriate mathematical framework developed for this purpose by adapting a linear programming model for the yearly decisions on which electricity generation source should be used to minimise the electricity generation cost. The model has been applied for the case of Greece. It should be noted that the life cycle approach seems to be vital in such analyses in order to improve the reliability of decision making. This is because there is a number of power generation technologies (mostly those based on renewable energy sources) which have almost zero externalities linked with the electricity generation phase, but the other stages of their life-cycle may have noteworthy effects on the environment.

The present paper is organised as follows: Section 2 concerns the literature review associated with this research. Section 3 presents the methodology used, analysing the LCA external cost estimation as well as the mathematical model. Results' presentation and discussion is the subject of Section 4, while Section 5 is about the sensitivity analysis performed in order to assess the reliability of the results. Finally, Section 6 highlights the main conclusions of the work.

\section{LITERATURE REVIEW}

\subsection{Life Cycle Assessment}

Life Cycle Assessment was originally developed to form a decisionmaking tool which is aimed at a systematic assessment of the environmental performance of production systems (Huybrechts et al., 1996; Steen, 2005). During the evolution of LCA a number of related applications emerged, such as decisionmaking support, choice of environmental performance indicators, product design 
and market claims etc. (Guinée et al., 2001; Vinodh and Rathod, 2009). It also provides a consistent basis for comparison between alternatives based on the environmental consequences associated with them (Georgakellos, 2012). However, results from an LCA can mainly be used for identification of parts and aspects of a life cycle where improvements in the environmental performance are important (Höjer et al., 2008; Graedel and Allenby, 2010).

The philosophy adopted by LCA is that the true extent of the environmental burden can only be understood if all steps in the delivery, use, and eventual disposal of the product or service are accounted for in the final analysis. The LCA methodology is described by four phases: (1) goal and scope definitions; (2) inventory analysis; (3) impact assessment; and (4) interpretation (Curran, 2006; Georgakellos, 2006). The foundation of a product's LCA is the inventory component where energy, raw materials and environmental releases are measured (Hassan, 2003; Ison and Miller, 2003). Specifically, the task in the inventory stage is to trace (ideally) all inputs to and outputs from every stage in the life cycle back to the associated terminal inputs to and outputs from nature (the environment). The flows may be segregated into inputs of materials and outputs of waste to air, land and water. In practice, it may not be possible to follow all of the input flows all the way back to the extraction of resources from the environment. However, this must be acknowledged in the study report and the consequences (for the use of the report) should be assessed (Georgakellos, 2005).

In the present work, the life cycle inventory concept is being used in order to quantify the atmospheric emissions associated with each power generation technology under examination. It is process-oriented, involving consideration of the individual technologies of interest. All energy systems are described on a 
"cradle to grave" basis, from the stage of extracting raw materials from the environment through downstream processes, with each stage in the chain being decomposed into construction, operation and dismantling phases (Dones et al., 1999). In the power sector, the assessment should include extraction, processing and transportation of fuels, building of power plants, production of electricity and waste disposal (Gagnon et al., 2002).

\subsection{External Cost of Power Generation Systems}

Almost every electricity generation option, aside from its beneficial consequences to society, causes undesirable effects, such as environmental degradation. Electricity production can influence a wide set of end points including soil, noise, visibility, global climate, human health, and visual amenity (Georgakellos, 2010). Common air pollutants that draw intense concerns include particulate matter $(\mathrm{PM})$, ozone $(\mathrm{O} 3)$, carbon monoxide $(\mathrm{CO})$, sulfur dioxide (SO2), nitrogen dioxide (NO2), lead ( $\mathrm{Pb}$ ), volatile organic compounds (VOCs), and polycyclic aromatic hydrocarbons (PAHs) (Han and Naeher, 2006).

Fossil fuel-fired power plants cause the biggest environmental pollution problem. Air pollution is caused by the high content of aliphatic hydrocarbons with impurities such as sulphur, water and other chemicals, the combustion of which results in the formation of effluents such as sulphur dioxide and oxides of nitrogen as well as carbon dioxide and particulate matters (PM) (Chaaban et al., 2004; Lora and Salomon, 2005). Moreover, other harmful constituents in the combustion gases are heavy metals, dioxins etc., which affect the life of humans, animals and plants (National Observatory of Athens, 2005).

In order to appraise the environmental impacts of various electricity production technologies, one of the most widely accepted approaches today relies 
on external costs of electricity production i.e. monetary value of damages. External costs are imposed on society (e.g. human health) and the environment (e.g. built environment, crops, forests and ecosystems) and are not accounted for by the producers or the consumers of electricity (Montanari, 2004). Generally, monetary estimates of both market and non-market damages are ideally expressed in the form of willingness to pay, or willingness to accept compensation (Fankhauser and Tol, 1996). Estimates of future economic damages resulting from atmospheric pollution have an important impact on policy decisions being made today. Reducing airborne emissions and protecting humanity from those impacts will be costly, but a failure to act to address these impacts would be even more expensive (Ackerman and Stanton, 2008).

On the other hand, European legislation is forcing Greece, together with all other EU member states, towards a secure, sustainable and competitive energy market. Thus, considering external costs due to the airborne emissions from conventional electricity generation systems is an important policy instrument towards sustainable energy use (Hondo, 2005). Several authors have attempted to publish estimates of annual climate change damages. The Intergovernmental Panel on Climate Change (IPCC) has concluded that the costs of reducing emissions to stabilise atmospheric greenhouse concentrations rise with successively lower levels of stabilisation (Hitz and Smith, 2004). Regarding the European continent, if the climate of the 2080s occurred today, the annual damage of climate change to the European Union economy in terms of GDP loss is estimated to be between 20 and 65 billion $€$, without public adaptation to this change. Damages would occur mainly in the Southern Europe and Central Europe 
North regions (Ciscar, 2009). Thus, Greece is among the countries that would be, very probably, significantly affected.

\subsection{Power Generation Modeling}

There has been significant research work devoted to the issue of defining the optimum electricity generating portfolio. Some of the first researchers to introduce the portfolio analysis in the Electricity Generation Sector were Bar-Lev and Katz (1976). More recent research (Awerbuch and Berger, 2003; Awerbuch, 2006; Bazilian and Roques, 2008) has extended the analysis to various power expansion mixes. Mean-variance portfolio techniques have been applied in various instances, introducing also various risk measures (Fortin et al., 2008; Roques et al., 2008).

Part of the relevant literature aims at optimizing the future power generation mix by using the Net Present Value (NPV) of the entire system examined as the optimization criterion. Some of the research works adopting this approach are the ones of Madlener et al. (2005), Xia et al. (2008) and Kumbaroglu et al. (2008). This approach requires forecasting of the future electricity prices in order to be able to provide results.

Another approach of optimizing energy portfolios is the one focusing on minimizing the electricity generation cost (Porat et al., 1997). The advantage of this approach is that no assumption over the future electricity prices is needed; therefore, one source of uncertainty may be eliminated. Focusing on minimum generation cost implies maximizing the potential for positive financial yields, irrespective of the electricity price. Equivalently, minimizing the generation cost may be considered as minimizing the cost to be passed on to the final consumers (Bagnall, 2004). 
There exist some commercially available tools following the latter approach, such as the Wien Automatic System Planning Program (WASP-IV), and the MARKAL. WASP and MARKAL are optimization models, using linear programming techniques to identify the least cost solution in meeting demand subjected to certain constraints. MARKAL is designed for the analysis of the overall energy system; however, it has also been applied to the electricity sector for analysing various scenarios and issues such as the internalization of external costs of electricity generation (Rafaj and Kypreos, 2007), the potential for CO2 emissions reduction (Cai et al., 2007), and future demand projections (Mondal et al., 2010). Another example of work adopting this approach is the one of Jaber et al. (2004), where medium-range planning economics of using alternative fuel options for electrical-power generation systems in Jordan is discussed using the levelised generation cost methodology to perform the comparison. Similarly, Akkemik (2009) has examined the electricity generation cost in Turkey, focusing mainly on determining scale economies, overcapitalisation, and technological progress for past years. The approach of minimizing the electricity generation cost is also adopted in this work.

Decision support tools have also been developed (Turton, 2008), aiming at globally optimal solutions taking into account financial and economic conditions and constraints imposed at an international level. Vithayasrichareon and McGill (2012) have presented a decision-support tool for assessing future generation portfolios. Furthermore, the important issue of the impact of uncertainty of energy prices on the supply structures and their interaction with the demand sectors has been analyzed in Krey et al. (2007). 
Several researchers have indulged in the issue of internalization of external costs in the electricity sector. Rafaj and Kypreos (2007) used the MARKAL model to perform an analysis for the world energy sector, divided into five extended regions. The researchers reached the conclusion that inclusion of external cost in the price of electricity increases the competitiveness of non-fossil generation sources and fossil power plants with emission control. In the work of Owen (2006), the conclusion was that if the estimates of damage costs resulting from fossil fuel electricity generation were internalized into the price of the resulting output of electricity, a number of renewable technologies (specifically wind and some applications of biomass) could be financially competitive with generation from coal plants. The issue of internalizing the external costs of generating electricity has been examined in several cases in the country level, such as in the case of Croatia (Bozicevic Vrhovcak et al., 2005) and Poland (Kudelko, 2006). In the latter case, heat generation was also included in the analysis.

\section{METHODOLOGY}

\subsection{Estimation of LCA External Cost of Electricity Generation Technologies}

Greece, like other European Union countries, depends heavily on imported energy since lignite is Greece's only significant fossil-fuel source. A considerable differentiation in structure of the country's energy balance is taking place mainly due to the large penetration of natural gas together with the renewable energy sources (Hellenic Republic, 2006). Greece is a country with a strong renewable energy potential, including wind, solar, biomass, geothermal and hydroelectric energy (International Energy Agency, 2006). 
In this context, the present work attempts to investigate the future electricity generation mix in Greece considering, among all other factors affecting it, the effect of the external cost associated with the atmospheric emissions released during the life cycle of the available electricity production technologies. The calculation of the external cost is based on the 'impact pathway' methodology which has been developed in the series of ExternE projects, and is further improved within NEEDS and other related on-going projects. The impact pathway analysis aims at modelling the causal chain of interactions from the emission of a pollutant through transport and chemical conversion in the atmosphere to the impacts on various receptors, such as human beings, crops, building materials or ecosystems. Welfare losses resulting from these impacts are transferred into monetary values based on the concepts of welfare economics (NEEDS, 2009). The impacts covered by the methods used for external cost assessment within NEEDS are Human Health, Loss of Biodiversity, Crop Yield and Material Damage. Regarding Climate Change, estimates of the damage costs of greenhouse gas emissions differ because the underlying integrated assessment models represent key climate and socio-economic relations differently. Furthermore, there are a number of assumptions to be made to which these estimates are highly sensitive. Thus, these issues cannot be resolved easily. The unit damage costs used for quantifying externalities from airborne pollutants and GHG are summarised in Table 1 (NEEDS, 2009). 
Table 1. Unit damage costs for air pollutants per impact category ${ }^{\text {a }}$

\begin{tabular}{|c|c|c|c|c|c|c|}
\hline \multirow[b]{2}{*}{ Pollutant } & \multirow[b]{2}{*}{ Unit } & \multicolumn{5}{|c|}{ Impact } \\
\hline & & health & biodiversity & $\begin{array}{l}\text { crop } \\
\text { yield }\end{array}$ & $\begin{array}{l}\text { material } \\
\text { damage }\end{array}$ & $\begin{array}{l}\text { climate } \\
\text { change }\end{array}$ \\
\hline NMVOC & $€ / \mathrm{t}$ & 941 & -70 & 189 & 0 & 0 \\
\hline NOx & $€ / \mathrm{t}$ & 5,722 & 942 & 328 & 71 & 0 \\
\hline PPM (2.5-10 $\mu \mathrm{m})$ & $€ / \mathrm{t}$ & 1,327 & 0 & 0 & 0 & 0 \\
\hline PPM $(<2.5 \mu \mathrm{m})$ & $€ / \mathrm{t}$ & $\begin{array}{r}24,57 \\
0\end{array}$ & 0 & 0 & 0 & 0 \\
\hline $\mathrm{SO}_{2}$ & $€ / t$ & 6,348 & 184 & -38 & 259 & 0 \\
\hline $\mathrm{CO}_{2}$ & $€ / \mathrm{t}$ & 0 & 0 & 0 & 0 & 7 \\
\hline
\end{tabular}

${ }^{a}$ (NEEDS, 2009)

The life cycle stages of each power generation technology under examination are not similar. For instance, the LCA systems of thermal power plants are more complicated than the ones of Renewable Energy Sources (RES) plants. This happens because in the former case the LCA system has to take into consideration the fuel production system apart from the plant construction. Evidently, this is not necessary in the RES case, with the only exception of biomass. The construction and operation in each stage (e.g. transportation, electricity generation) were examined in this work, while the decommissioning in each stage was excluded. It should be noted that a quantification of the decommissioning stage of infrastructure, buildings, machinery, etc. is not available in the majority of studies published, due to the lack of trustworthy data (e.g. Graebig et al., 2010; Fruergaard et al., 2010; Kaldellis et al., 2010; Jing et al., 2012).

Subsequently, Table 2 includes LCA atmospheric emission factors concerning the best currently available technology of various electricity generation plants, as reported in the literature. However, regarding some of them (mainly the hydroelectric power plant and the oil-fired power plant), these data refer to the present-day technology of actual plants in Greece because these 
technologies are either strongly site-specific (hydroelectric power plants) or rather mature (oil-fired power plants). In particular, the LCA airborne pollutants of the hydroelectric power plant have been estimated based on direct relevant information given by PPC Renewables SA (the subsidiary for renewables of Public Power Corporation - PPC, the major electricity producer in Greece). The information concerns a large hydroelectric power plant $(2 \times 85 \mathrm{MW})$ with dam in Greece. Specifically, its construction required:

- $153,200 \mathrm{~m}^{3}$ of concrete,

- $8,800,000 \mathrm{~m}^{3}$ of clay, sand and gravel, aggregates etc,

- $1,775,000 \mathrm{~kg}$ of steel,

- $\quad 11,892,568.2$ litres of diesel.

The average annual production of energy is about $320 \mathrm{GWh} / \mathrm{y}$, while its lifespan is approximately 100 years. For the calculation of the emission factors the following has been considered: the LCA NMVOC (non-methane volatile organic compounds), NOx, and PM emission factors of concrete for Greece are 0.0028, $0.0105,0.0009 \mathrm{~kg} / \mathrm{m}^{3}$ respectively (Biska and Oikonomou, 2006); the LCA NMVOC, NOx, $\mathrm{PM}$ and $\mathrm{SO}_{2}$ emission factors of steel (hot rolled coil) are 0.00072, 0.0078, 0.00372 and $0.0052 \mathrm{~kg} / \mathrm{kg}$ respectively (Dones, et al. 2007; WSA, 2011); the combustion of 1 litre of diesel fuel produces around 0.003, $0.0623,0.0003$ and $0.0015 \mathrm{~kg}$ of NMVOC, NOx, $\mathrm{PM}$ and $\mathrm{SO}_{2}$ respectively (Lawson, 2007); the LCA $\mathrm{SO}_{2}$ emission factor of aggregates is $1.48 \times 10^{-5} \mathrm{~kg} / \mathrm{kg}$, which has been calculated considering that the bulk density of sand and gravel is $1300-2000 \mathrm{~kg} / \mathrm{m}^{3}$ and of clay at mine is $2000 \mathrm{~kg} / \mathrm{m}^{3}$ (Kellenberger et al., 2007; Korre and Durucan, 2009). The $\mathrm{CO}_{2} \mathrm{LCA}$ emission factor of the hydroelectric 
power plant refers to the same plant, as it has been reported in the literature (Georgakellos, 2012). 
Table 2. Life cycle air pollutants emission factors of various electricity generation technologies

\begin{tabular}{|c|c|c|c|c|c|c|c|c|c|c|}
\hline \multirow{2}{*}{ Pollutant } & \multirow{2}{*}{ Unit } & \multicolumn{9}{|c|}{ Fuel / RES Type } \\
\hline & & Lignite $^{\text {a }}$ & Hard Coal $^{\text {a }}$ & Natural Gas ${ }^{a}$ & Oil $^{b}$ & Biomass $^{\text {a }}$ & Hydro $^{c}$ & $\mathbf{P V}^{\mathbf{a}}$ & Wind $^{d}$ & Geothermal $^{\mathrm{e}}$ \\
\hline NMVOC & $\mathrm{kg} / \mathrm{kWh}$ & $2.36 \mathrm{E}-05$ & 5.94E-05 & $1.01 \mathrm{E}-04$ & $3.45 \mathrm{E}-05$ & $2.22 \mathrm{E}-04$ & $1.17 \mathrm{E}-06$ & 7.09E-05 & $8.05 \mathrm{E}-06$ & $0.00 \mathrm{E}+00$ \\
\hline NOx & $\mathrm{kg} / \mathrm{kWh}$ & 7.38E-04 & 8.07E-04 & $3.09 \mathrm{E}-04$ & $6.34 \mathrm{E}-03$ & $1.76 \mathrm{E}-03$ & $2.36 \mathrm{E}-05$ & $1.36 \mathrm{E}-04$ & $3.86 \mathrm{E}-05$ & $2.00 \mathrm{E}-05$ \\
\hline PPM (2.5-10 $\mu \mathrm{m})$ & $\mathrm{kg} / \mathrm{kWh}$ & 7.61E-05 & $7.48 \mathrm{E}-05$ & $1.23 \mathrm{E}-05$ & $1.20 \mathrm{E}-04$ & $4.86 \mathrm{E}-05$ & $3.22 \mathrm{E}-07$ & $4.73 \mathrm{E}-05$ & $1.17 \mathrm{E}-05$ & $1.00 \mathrm{E}-05$ \\
\hline PPM $(<2.5 \mu \mathrm{m})$ & $\mathrm{kg} / \mathrm{kWh}$ & $6.47 \mathrm{E}-05$ & 5.31E-05 & $8.22 \mathrm{E}-06$ & $0.00 \mathrm{E}+00$ & $4.25 \mathrm{E}-05$ & $0.00 \mathrm{E}+00$ & 2.37E-05 & $0.00 \mathrm{E}+00$ & $0.00 \mathrm{E}+00$ \\
\hline $\mathrm{SO}_{2}$ & $\mathrm{~kg} / \mathrm{kWh}$ & $1.69 \mathrm{E}-04$ & $6.18 \mathrm{E}-04$ & $1.47 \mathrm{E}-04$ & $6.16 \mathrm{E}-04$ & $5.31 \mathrm{E}-04$ & 8.99E-06 & 2.33E-04 & 3.83E-05 & $2.71 \mathrm{E}-03$ \\
\hline $\mathrm{CO}_{2}$ & $\mathrm{~kg} / \mathrm{kWh}$ & $9.21 \mathrm{E}-01$ & $7.76 \mathrm{E}-01$ & $3.98 \mathrm{E}-01$ & $6.74 \mathrm{E}-01$ & $1.80 \mathrm{E}-02$ & $2.51 \mathrm{E}-03$ & $5.52 \mathrm{E}-02$ & $9.56 \mathrm{E}-03$ & $1.31 \mathrm{E}-01$ \\
\hline
\end{tabular}

a (NEEDS. 2009)

${ }^{\mathrm{b}}$ (Pyrovolakis and Georgakellos. 2005)

${ }^{c}$ Own calculations and (Georgakellos. 2012)

${ }^{\mathrm{d}}$ (Dones et al.. 2007)

e (Fritsche and Rausch. 2009) 
External costs are calculated by multiplying the relevant life cycle inventory data presented in Table 2 with the unit damage costs derived from Table 1. The results are shown in Table 3, analysed per impact type (human health, loss of biodiversity, crop yield, material damage and climate change).

Table 3. Atmospheric emissions' life cycle external cost of the electricity generation technologies examined

\begin{tabular}{|c|c|c|c|c|c|c|c|}
\hline \multirow[b]{2}{*}{ Fuel/RES Type } & \multirow[b]{2}{*}{ Unit } & \multicolumn{5}{|c|}{ Impact type } & \multirow[b]{2}{*}{ Total } \\
\hline & & Health & Biodiversity & $\begin{array}{l}\text { Crop } \\
\text { Yield }\end{array}$ & $\begin{array}{l}\text { Material } \\
\text { Damage }\end{array}$ & $\begin{array}{l}\text { Climate } \\
\text { Change }\end{array}$ & \\
\hline Lignite & $€ / \mathrm{kWh}$ & 7.01E-03 & $7.25 \mathrm{E}-04$ & $2.40 \mathrm{E}-04$ & $9.62 \mathrm{E}-05$ & $6.45 \mathrm{E}-03$ & $1.45 \mathrm{E}-02$ \\
\hline Hard Coal & $€ / \mathrm{kWh}$ & $1.00 \mathrm{E}-02$ & 8.70E-04 & $2.52 \mathrm{E}-04$ & $2.17 \mathrm{E}-04$ & $5.43 \mathrm{E}-03$ & $1.68 \mathrm{E}-02$ \\
\hline Natural Gas & $€ / \mathrm{kWh}$ & $3.01 \mathrm{E}-03$ & $3.11 \mathrm{E}-04$ & $1.15 \mathrm{E}-04$ & $6.00 \mathrm{E}-05$ & $2.79 \mathrm{E}-03$ & $6.29 \mathrm{E}-03$ \\
\hline Oil & $€ / \mathrm{kWh}$ & 4.03E-02 & $6.08 \mathrm{E}-03$ & $2.06 \mathrm{E}-03$ & $6.09 \mathrm{E}-04$ & 4.72E-03 & 5.38E-02 \\
\hline Biomass & $€ / \mathrm{kWh}$ & $1.48 \mathrm{E}-02$ & $1.74 \mathrm{E}-03$ & 5.99E-04 & 2.62E-04 & $1.26 \mathrm{E}-04$ & $1.75 \mathrm{E}-02$ \\
\hline Hydro & $€ / \mathrm{kWh}$ & $1.94 \mathrm{E}-04$ & $2.38 \mathrm{E}-05$ & 7.62E-06 & $4.00 \mathrm{E}-06$ & $1.76 \mathrm{E}-05$ & 2.47E-04 \\
\hline PV & $€ / \mathrm{kWh}$ & $2.97 \mathrm{E}-03$ & $1.66 \mathrm{E}-04$ & 4.92E-05 & $7.00 \mathrm{E}-05$ & $3.86 \mathrm{E}-04$ & 3.64E-03 \\
\hline Wind & $€ / \mathrm{kWh}$ & 4.87E-04 & $4.28 \mathrm{E}-05$ & $1.27 \mathrm{E}-05$ & $1.27 \mathrm{E}-05$ & $6.69 \mathrm{E}-05$ & $6.22 \mathrm{E}-04$ \\
\hline Geothermal & $€ / \mathrm{kWh}$ & $1.73 \mathrm{E}-02$ & $5.17 \mathrm{E}-04$ & $-9.64 \mathrm{E}-05$ & 7.03E-04 & $9.14 \mathrm{E}-04$ & $1.94 \mathrm{E}-02$ \\
\hline
\end{tabular}

It should be noted however, that taking into account the overall uncertainties related to both the quantification of external costs as well as to the life cycle specification of different electricity generation technology configurations, the data of Table 3 provide rather external cost estimates for typical average configurations than detailed external cost information. Thus, they indicate the order of magnitude of externalities from the electricity generation technologies examined here. For this reason, the external costs have been considered as one of the major parameters to examine in the sensitivity analysis of the model results that follows. 


\subsection{The Model}

In the analysis, ten different electricity generation methods have been included in the examination, corresponding to nine different fuel sources (as seen in Table 2 and Table 5). Each fuel source is represented by one electricity generation technology with the exception of hydroelectric power, where the hydroelectric pumped-storage plant type is considered separately from typical hydroelectric power plants. For every case, the best available technology has been selected. The choice of the technologies included for the case study is that all currently commercially available conventional and RES should be included in the work apart from nuclear power, which is strategically excluded from the electricity generation mix of Greece since many years.

The Levelised Lifetime Cost Estimation Methodology (IEA, 2005) has been used to calculate the electricity generating cost for each year and each technology, as it is considered one of the most important indicators for evaluating fiscal performance of power supply systems (Gokcek and Genc, 2009) in the relevant literature. The levelised lifetime cost per unit of electricity generated is the ratio of total lifetime expenses versus total expected outputs, both of which are expressed in terms of present value equivalent. The original methodology has been expanded to match the specific requirements of this work. This methodology has been chosen instead of traditional Net Present Value analysis, as it transforms the investments and the time series of expenditures and incomes during the lifetime of the investment to equal annuities, discounted in Present Value. Therefore, it allows fair comparison of the electricity generation cost even for power plants installed in years close to the boundary of the time-period examined, when traditional NPV analysis would fail to provide reliable results, as only part of the lifetime of the power plant would be included in the calculations. The model used in this work is primarily based on 
Rentizelas et al. (2012) with the appropriate extension to incorporate the internalization of external costs and several changes in the constraints of the optimization model. The relevant notations are given in Table 4 .

Table 4. Notations

\begin{tabular}{|c|c|}
\hline Indices & Description \\
\hline$i$ & Technologies included in the study \\
\hline$t$ & Years $[2012,2050]$ \\
\hline Sets & Description \\
\hline REN & Renewable technologies \\
\hline CONV & Conventional technologies \\
\hline Parameters & Description \\
\hline$A I_{i, t}$ & Investment annuities $(€ / \mathrm{MWel} /$ year) \\
\hline$C f_{i, t}$ & Fuel cost $(€ / \mathrm{MWh}$ fuel $)$ \\
\hline $\mathrm{Cco} 2_{t}$ & Forecasted $\mathrm{CO} 2$ price in year $\mathrm{t}(€ /$ tn $\mathrm{CO} 2)$ \\
\hline $\mathrm{CO} 2_{i, t}$ & Total emissions allowance cost for year $\mathrm{t}$ and conventional tech. i (€/MWel) \\
\hline$E_{i}$ & Energy generated yearly from unitary capacity of technology i (MWh/MWel) \\
\hline Edem $_{t}$ & Energy demand in year $\mathrm{t}(\mathrm{MWh})$ \\
\hline$E G C_{i, t}$ & Average levelised lifetime electricity generation cost $(€ / \mathrm{MWh})$ \\
\hline Emco $_{i}$ & $\mathrm{CO} 2$ emissions of technology i (tnCO2/MWh electr.) \\
\hline$E_{x}$ & Externality costs of technology i per year $(€ / M W e l)$ \\
\hline$F_{i, t}$ & Total fuel cost for year $t$ and technology i (€/MWel) \\
\hline$I_{i, t}$ & Investment cost per unit of capacity installed ( $€ / \mathrm{MWel})$ \\
\hline$O M f_{i, t}$ & Fixed Operational \& Maintenance costs $(€ / \mathrm{kWel})$ \\
\hline$O M v_{i, t}$ & Variable Operational \& Maintenance costs $(€ / \mathrm{MWel})$ \\
\hline$P c l_{i, t}$ & Capacity of tech. i scheduled to be decommissioned in year $\mathrm{t}(\mathrm{MWel})$ \\
\hline Pdem $_{t}$ & Peak-load demand in year t (MWel) \\
\hline $\operatorname{Pmax}_{i}$ & Maximum resource potential of technology i (MWel) \\
\hline Ptot $_{i, t}$ & Installed capacity of technology i in year t (MWel) \\
\hline$Q_{i, t}$ & Projected global installed capacity of technology i in year t (GW) \\
\hline Top $_{i}$ & Operational lifetime of technology i (Years) \\
\hline$b_{i}$ & Learning rate of technology $i$ \\
\hline$f a v_{i}$ & Availability factor of technology i \\
\hline$f_{c a p}$ & Capacity factor of technology i \\
\hline$n_{i}$ & Efficiency factor of technology i \\
\hline$r$ & Interest rate \\
\hline
\end{tabular}

The average levelised lifetime electricity generation cost EGC is: 
$E G C_{i, t}=\sum_{n=t}^{T}\left[\left(A I_{i, t}+O M f_{i, n}+O M v_{i, n}+F_{i, n}+C O 2_{i, n}+E x t_{i}\right)(1+r)^{-t}\right] / \sum_{n=t}^{T}\left[E_{i}(1+r)^{-t}\right]$

$\forall i, \mathrm{t} \in[2012,2050], T=\min \left(t+\right.$ Top $\left._{i}, 2050\right)$.

It should be noted that scaling factors have been removed from the equations for simplicity. Furthermore, the externality costs for each technology $E x t_{i}$ have been expressed in Euros per MWel installed by multiplying the values from Table 3 with $E_{i}$ , namely the amount of electricity generated yearly from 1 MWel capacity installed.

The investment cost is calculated as a series of equal annuities spread over the entire lifetime of each specific technology. The rationale is to allow reliable calculations also for the years $t$ when the operational lifetime of a specific technology is longer than the remaining time period for examination. The annuities are calculated using the following equation:

$$
A I_{i, t}=\frac{I_{i, t} \cdot r}{\left(1-(1+r)^{-T o p_{i}}\right)} \quad \forall i, \mathrm{t} \in[2012,2050]
$$

The calculation of the investment cost $I_{i, t}$ includes the learning effect from the projected increase in global installed capacity for each specific technology using the equation:

$$
I_{i, t}=I_{i, t 0} \cdot\left[\frac{Q_{i, t}}{Q_{i, t 0}}\right]^{\log _{2}\left[1-b_{i}\right]} \quad \forall i, \mathrm{t} \in[2012,2050],
$$

where $t 0$ is the reference year (equal to year 2012).

The fuel cost per unit of capacity of each technology is calculated as

$$
F_{i, t}=\frac{E_{i}}{n_{i}} C f_{i, t} \quad \forall i, \mathrm{t} \in[2012,2050]
$$

where the energy generated from a unit of capacity of each technology is

$$
E_{i}=8760 \cdot f a v_{i} \cdot f_{c a p} \quad \forall i
$$


The availability factor $f a v_{i}$ is defined as the ratio of time a power plant is technically available to generate energy to the total time in the examined period. The main reasons for reduced availability factor values are maintenance and repairs. The capacity factor $f_{c a p}$ of a power plant is defined as the ratio of its actual energy output over a period of time to its potential output if it were possible for it to operate at full capacity for the same period. The capacity factor may be reduced due to lack of electricity demand, low electricity prices and, especially for some Renewable Energy Sources, unavailability of appropriate primary energy source (wind, solar radiation, water etc.).

The cost of obtaining the emission allowances for the power plants using conventional fuel sources is calculated as

$$
C O 2_{i, t}=E_{i} \cdot \operatorname{Emco}_{i} \cdot C \operatorname{Co} 2_{t} \quad \forall i \in C O N V .
$$

The Operational and Maintenance cost $(\mathrm{O} \& \mathrm{M})$ is distinguished into variable $(O M v$ - proportional to the energy generated) and fixed (OMf).

The optimization problem is modeled as a linear programming model. In order to sustain linearity, a series of yearly decisions is modeled. Each yearly decision concerns the capacity of each one of the examined electricity generation technologies to be added to the current generation mix, in order to meet the electricity demand increase. Consequently, for each yearly decision, the number of variables $X_{i}$ is equal to the number of technologies examined.

The objective function of the optimization problem, which is to be minimized, is the cost of generating the excess energy required in the year examined.

$$
f(x)=\min \sum_{i} E_{i} \cdot E G C_{i, t} \cdot X_{\mathrm{i}} \quad \forall t
$$

There are several constraints in this optimization model. The first set of constraints (8) and (9) refer to the power and energy demand. Constraint (8) ensures 
that the total installed generating capacity is adequate to serve the peak-load demand in order to secure uninterrupted supply of demand. Due to the long-term horizon of this study, a simplified approach has been adopted: the contribution of each technology to the peak load coverage is considered proportional to its capacity factor; i.e. technologies with low capacity factors, such as PV or wind, are considered to contribute only a small fraction of their nominal installed capacity to the peak load coverage, due to their erratic generation timing. This approach constitutes a change to the model of Rentizelas et al. (2012).

$$
\text { Pdem }_{t} \leq \sum_{i}\left(\text { Ptot }_{i, t} * \text { fcap }_{i}\right)
$$

Furthermore, constraint (9) requires that the energy produced will be enough to satisfy yearly energy demand, increased by a certain percentage (in this work 5\%) to account for the electricity transmission losses. The inclusion of the transmission system losses is another modification of the model compared to Rentizelas et al. (2012).

$$
\text { Edem }_{t} * 105 \% \leq \sum_{i} E_{i} \cdot \text { Ptot }_{i, t}
$$

The total installed capacity for each technology and each year $\left(\right.$ Ptot $\left._{i, t}\right)$ is calculated in a recursive way. More specifically, it is equal to the installed capacity for the specific technology of the previous year than the one examined (Ptot $\left.{ }_{i, t-1}\right)$, plus the new generation capacity installed during the year examined $\left(X_{i}\right)$, minus the old generation capacity that has reached its operational lifetime during the same year $\left(P c l_{i, t}\right)$ :

$$
\text { Ptot }_{i, t}=\text { Ptot }_{i, t-1}+X_{i}-P_{c l} \quad \forall i
$$

The set of constraints (11) expresses the fact that there exists only a certain exploitable amount of some RES. In this work it has been assumed that the maximum 
installed capacity of wind, hydro and geothermal power must be less than the respective identified national potential, at all times. Biomass and solar PV energy potentials have not been included in this study, due to the inherent difficulty in determining their potential.

Ptot $_{i, t} \leq P \max _{i} \quad i \in($ wind, hydro, geothermal $)$

Constraint (12) aims to take into account a technical aspect of the electricity system, which is grid stability. The fact that most RES cannot be dispatched when required, as they strongly depend on weather conditions, prevents them from constituting a reliable base-load solution in the long term. This issue is primarily applicable to wind parks and solar PV energy, and to some extent, to hydro-power and biomass. Despite their short setup periods and zero fuel requirements, they often suffer from resource unavailability. Thus, unpredictable conditions might impact the stability of the national grid and the reliability of power supply. Despite the fact that there is no consensus on the maximum allowable percentage of renewable energy infusion to secure the grid stability, scientists agree that there is currently an upper limit on renewable power penetration to the grid (Weigt, 2009). For this reason a constraint is imposed ensuring that the total energy production from RES may not exceed $50 \%$ of the total energy demand.

$$
\sum_{i \in R E N} E_{i} \cdot \text { Ptot }_{i, t} \leq 50 \% \sum_{i} E_{i} \cdot \text { Ptot }_{i, t}
$$

The next constraint (13) reflects the current national renewable energy targets which require that $40 \%$ of the total electricity from year 2020 onwards should be generated by RES. In order to facilitate the model operation, this target has been linearly shared to the years until 2020, starting from a 10\% RES share for the year 2010. 
$\sum_{i \in R E N} E_{i} \cdot$ Ptot $_{i, t} \geq 40 \% \sum_{i} E_{i} \cdot$ Ptot $_{i, t} \quad t \in[2020,2050]$

Finally, the logical non-negativity constraints for the optimization variables are modeled as constraints (14) and (15). Additionally, an arbitrary upper limit equal to $1500 \mathrm{MW} / y e a r$ for every conventional power technology and $1000 \mathrm{MW} / \mathrm{year}$ for every RES has been applied, in order to avoid the unnatural case where only one power source dominates the market in one year.

$0 \leq X_{i} \leq 1500 \quad i \in C O N V$

$0 \leq X_{i} \leq 1000 \quad i \in R E N$

Due to the significant $\mathrm{CO}_{2}$ allowance price fluctuations, the uncertainty has been taken into account in this work by examining two scenarios of its price evolution. These scenarios have been derived from processing the results of the Zephyr-Flex model (Climate Economics Chair, 2012). The two extreme scenarios of the Zephyr-Flex model have been adopted in this work (the optimistic and pessimistic ones, named hereby as High and Low $\mathrm{CO}_{2}$ price scenarios). As the Zephyr-Flex model provided only expected values of $\mathrm{CO}_{2}$ allowance price for the years 2012 and 2020, a linear interpolation has been performed for the values between these years and a linear extrapolation for the years after 2020. The $\mathrm{CO}_{2}$ price scenarios used in this work are presented in Figure 1. 


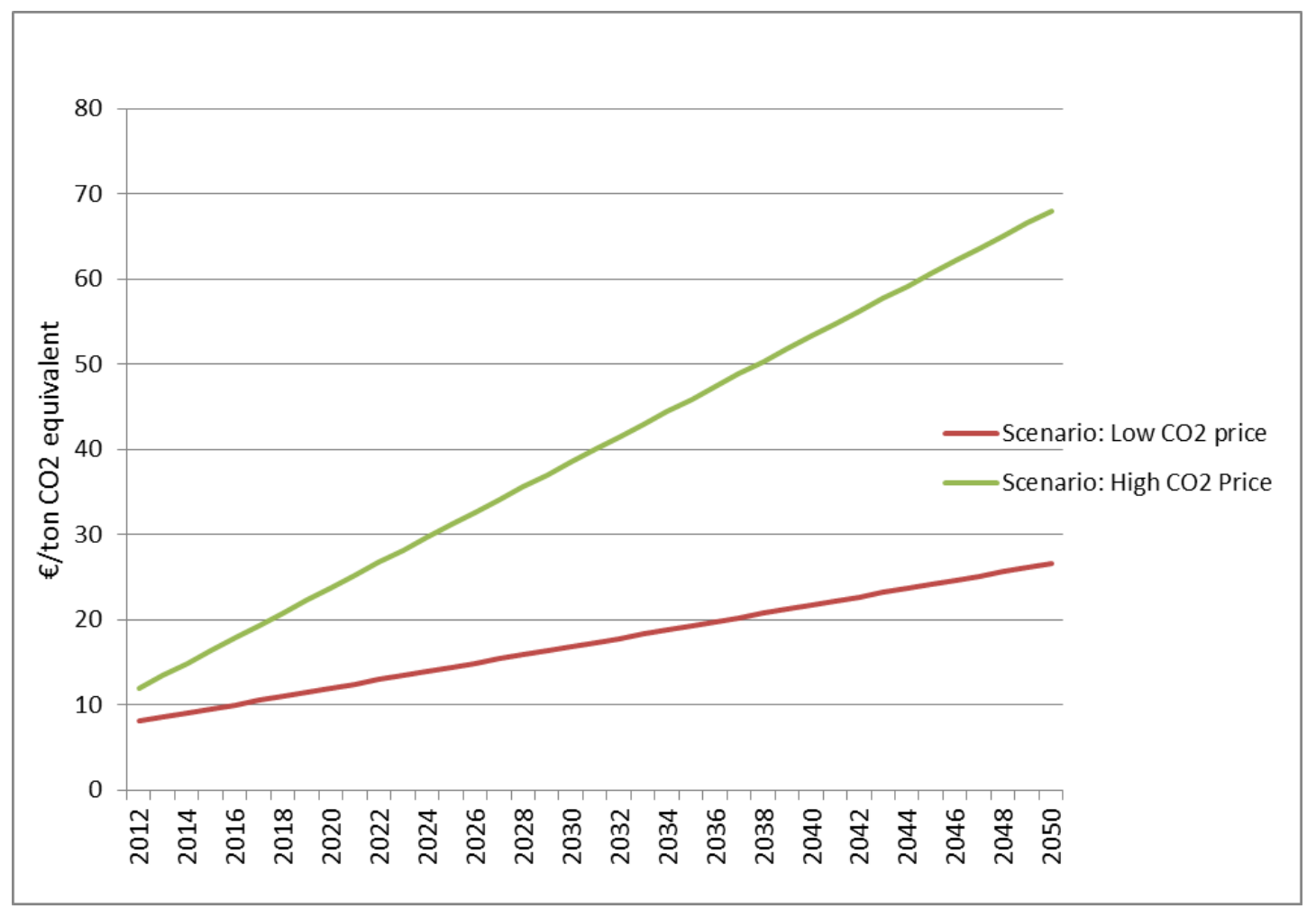

Figure 1. $\mathrm{CO}_{2}$ price scenarios

Several assumptions were made to realize the model presented in this work.

First of all, it has been assumed that conventional-fuel electricity generators will have to purchase the full amount of the emission allowances they require for electricity generation. In relation to this, it is also assumed that the renewable energy generators will not be able to trade the green certificates or emissions reduction allowances from the energy they generate, as the status is not the same in all countries at the moment, and it is not clear whether it will be possible to do so in the future. The potential income from trading emission allowances or green certificates should be included in the calculations, thus reducing the respective generation cost in cases where the specific installations are eligible. Another assumption is that the inflation rate has not been included in the analysis, which means that all future values used are deflated to real values. The interest rate $r$ has been assumed equal to $8 \%$. This work takes into 
account the real electricity generation cost of all technologies without any kind of subsidies, as any type of subsidies are ultimately passed on to the final consumers (directly or indirectly) and finally increase the generation cost. Finally, the minimum effective scale and minimum effective capacity increase for each technology have not been taken into account in this work as constraints, to avoid over-restricting the domain of the variables. The main inputs of the model are presented in Table 5. In Table 6, one may see the estimated future evolution of the fuel prices. For reasons of space limitations, fuel prices are presented for some of the years of the period of the analysis. 
Table 5: Input data of the model ${ }^{\text {a }}$

\begin{tabular}{|c|c|c|c|c|c|c|c|c|c|c|}
\hline & : & $\bar{\sigma}$ & 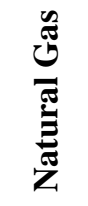 & 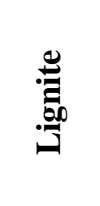 & 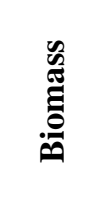 & $\frac{1}{\pi}$ & 串 & 窇苞 & 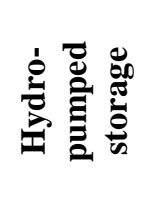 & 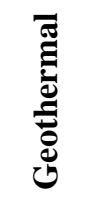 \\
\hline Investment cost $\left(€ / K W_{\text {el }}\right)$ & 1295 & 1150 & 697 & 1050 & 2200 & 2222 & 1100 & 1300 & 3400 & 1800 \\
\hline Fixed cost $(O \& M$, insurance etc. $)\left(€ / \mathbf{k} W_{\mathrm{el}}\right)$ & 56.4 & 38 & 18.8 & 35 & 19 & 30 & 18 & 3 & 50 & 32 \\
\hline Variable cost $\left(€ / M W h_{\text {el }}\right)$ & 3.2 & 1.6 & 1.6 & 1 & 0 & 0 & 0 & 1.5 & 1.5 & 18 \\
\hline Availability factor & 0.9 & 0.85 & 0.75 & 0.9 & 0.85 & 0.99 & 0.98 & 0.98 & 0.92 & 0.7 \\
\hline Capacity factor & 0.85 & 0.8 & 0.85 & 0.85 & 0.85 & 0.17 & 0.27 & 0.25 & 0.4 & 0.9 \\
\hline Learning rate & 0.01 & 0.01 & 0.01 & 0.01 & 0.15 & 0.2 & 0.1 & 0 & 0 & 0 \\
\hline Efficiency Factor & 0.46 & 0.45 & 0.6 & 0.41 & 0.3 & 1 & 1 & 1 & 1 & 1 \\
\hline Financial Life-Time (Years) & 40 & 40 & 30 & 40 & 40 & 25 & 20 & 40 & 40 & 40 \\
\hline
\end{tabular}

a (Caralis et al., 2008; IEA, 2005; IEA, 2010; Kumbaroglu et al., 2008) 


\begin{tabular}{lccccc}
\hline & Hard-coal & Oil & Natural Gas & Lignite & Biomass \\
& & & & & \\
\hline $\mathbf{2 0 1 2}$ & 6.55 & 30.78 & 16.34 & 3.74 & 5.96 \\
$\mathbf{2 0 2 0}$ & 6.84 & 44.85 & 18.36 & 4.32 & 6.51 \\
$\mathbf{2 0 3 0}$ & 7.56 & 50.24 & 20.88 & 5.04 & 7.27 \\
$\mathbf{2 0 4 0}$ & 8.28 & 55.90 & 23.76 & 5.40 & 8.10 \\
$\mathbf{2 0 5 0}$ & 9.00 & 62.20 & 26.28 & 6.12 & 9.04 \\
\hline
\end{tabular}

\section{RESULTS AND DISCUSSION}

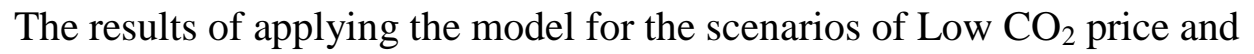
High $\mathrm{CO}_{2}$ price are presented. The result charts are grouped by $\mathrm{CO}_{2}$ price level for the scenarios to allow focusing on the effect of including the external cost in the calculations. Figures 2 and 3 present the new generating capacity installed each year for each one of the fuels/technologies examined.

For Low $\mathrm{CO}_{2}$ prices, it is interesting to note that if external cost is not taken into account, the RES employed are wind, geothermal and biomass (Figure 2). If externalities are included in the calculations, the model introduces the use of hydroelectric energy, mainly displacing biomass-generated energy. The introduction of new hydro-power takes place mainly within the first 8 years of the period examined, whereas only small amounts of new hydro-power generating capacity are introduced at later stages, replacing older hydro-power plants that reach their life limit. This fact may be attributed to the external cost of biomass being two orders of magnitude higher than that of hydro-power. As far as conventional energy sources are concerned, the model results in using only natural 
gas apart from the first year, when the maximum yearly limit for new capacity of natural gas is reached, thus lignite is also used.

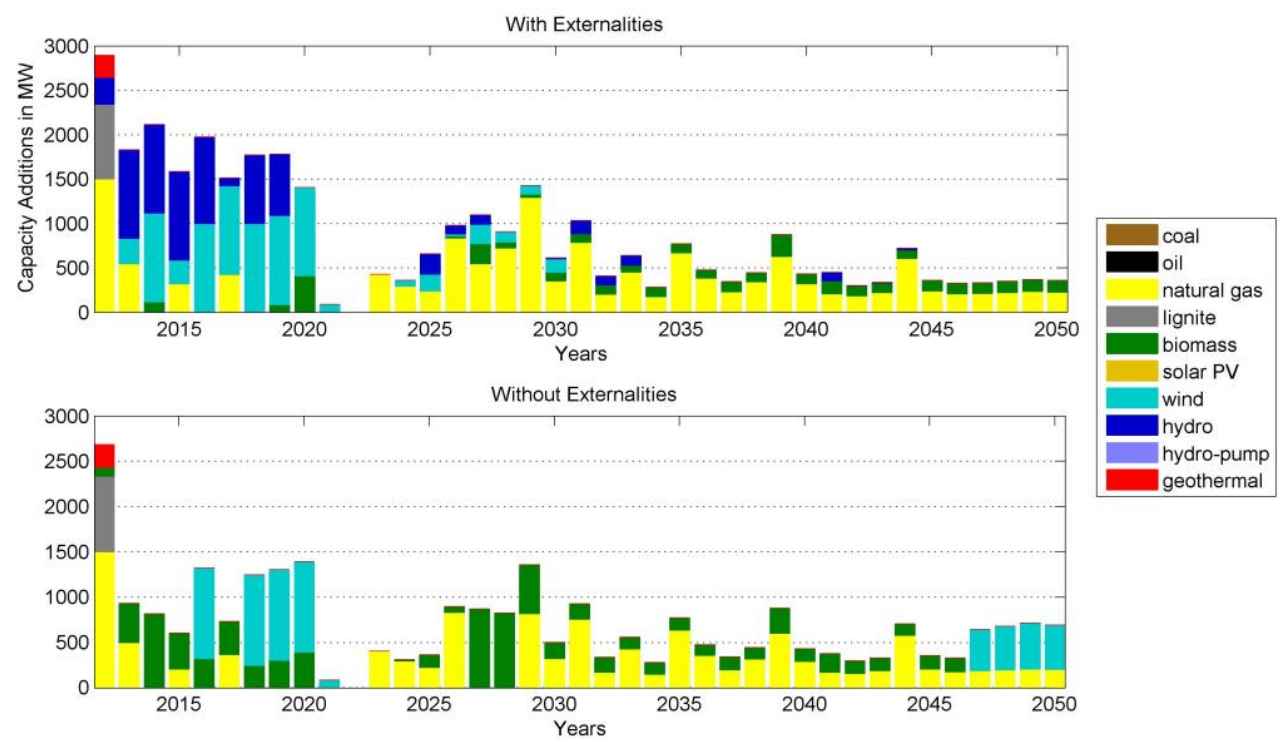

Figure 2. Yearly capacity additions - Low $\mathrm{CO}_{2}$ prices scenario

In the scenario of $\mathrm{High} \mathrm{CO}_{2}$ prices (Figure 3), the main findings resemble the case of Low $\mathrm{CO}_{2}$ prices, meaning that hydro-power is employed only when the external cost is included in the calculations. The dominating RES technologies are biomass and wind if externalities are not taken into account. When externalities are accounted for, wind and hydro-power are mainly used. The only conventional fuel source used in these scenarios is natural gas. High $\mathrm{CO}_{2}$ prices lead to increased RES penetration in both cases (with or without externalities), as compared to the Low $\mathrm{CO}_{2}$ prices case. The high prices of $\mathrm{CO}_{2}$ increase the generating cost of conventional fuel sources, and therefore RES become costcompetitive at an earlier point in time. 


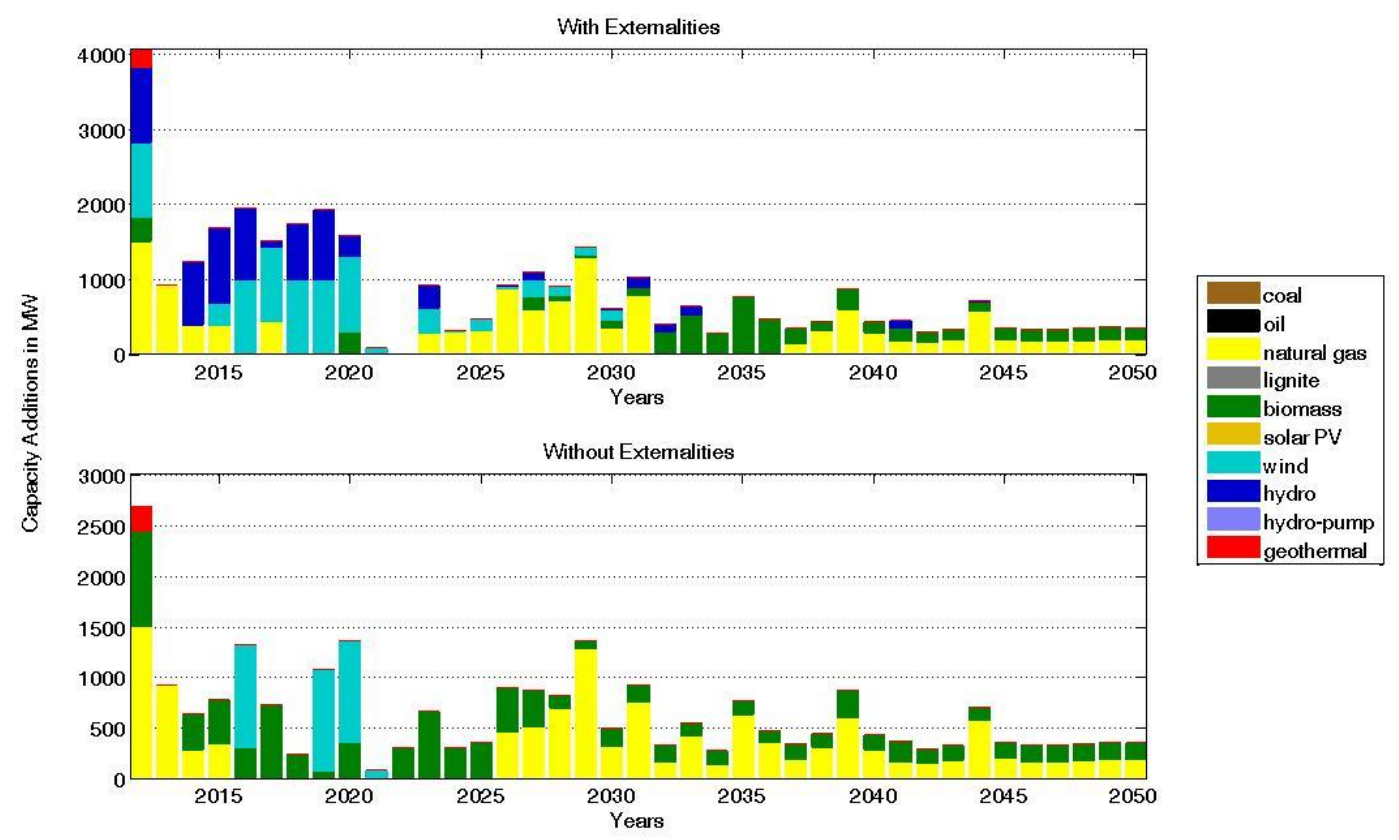

Figure 3. Yearly capacity additions - High $\mathrm{CO}_{2}$ prices scenario

Figures 4 and 5 present the evolution of the total energy mix for each one of the four scenarios examined, including the existing generation capacity prior to the period of analysis, until the existing capacity is decommissioned. Again, the finding that hydro-power is used extensively in the scenarios where external cost is examined, is apparent. It is also obvious that hydro-power and wind energy generation are replacing biomass, compared to the scenarios without externalities. It is interesting to note that in the high $\mathrm{CO}_{2}$ price scenarios, the only conventional fuel source used in the year 2050 is the natural gas, due to its cost advantage against the other conventional fuel sources. In the low $\mathrm{CO}_{2}$ price scenarios, there remains also a small fraction of the original lignite capacity. Furthermore, in the high $\mathrm{CO}_{2}$ price - without externalities - scenario, the main energy sources are natural gas and biomass, with only small fractions of the total energy demand being generated by wind, hydro-power and geothermal. If externalities are taken 
into account, the final generating mix of the year 2050 is more balanced, including significant amounts of energy generated by wind and hydro-power plants.

It is therefore apparent by Figures 4 and 5 that including externalities cost in the electricity generation cost estimation would lead to a significantly different electricity generating mix in the future. If externalities are taken into account, more than half of the energy would be generated by natural gas by 2050 and the remaining would be almost equally shared between biomass, wind and hydropower. If externalities are not taken into account, biomass and natural gas are the two prevailing energy sources with roughly equal share in the year 2050, and with significantly reduced amounts of wind and hydro-power compared to the previous case.
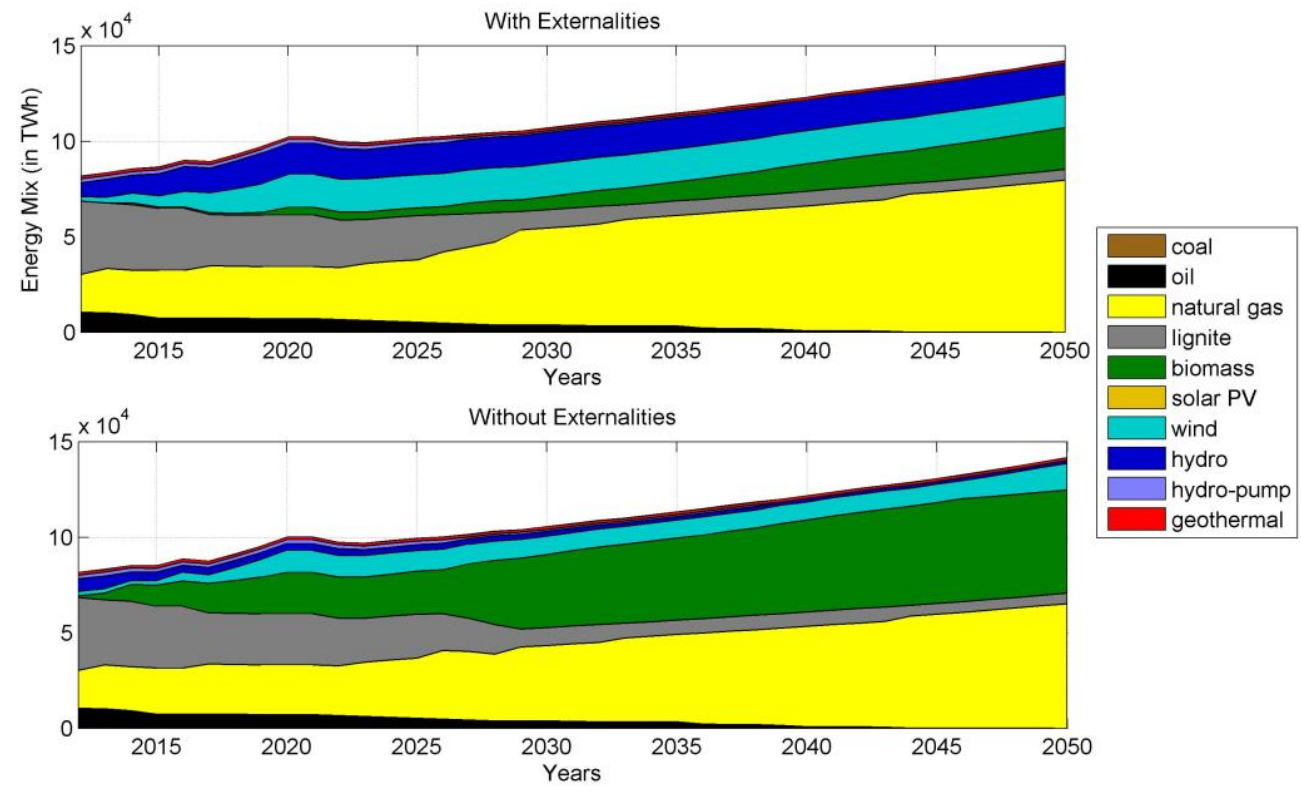

Figure 4. Energy mix - Low $\mathrm{CO}_{2}$ prices scenario 


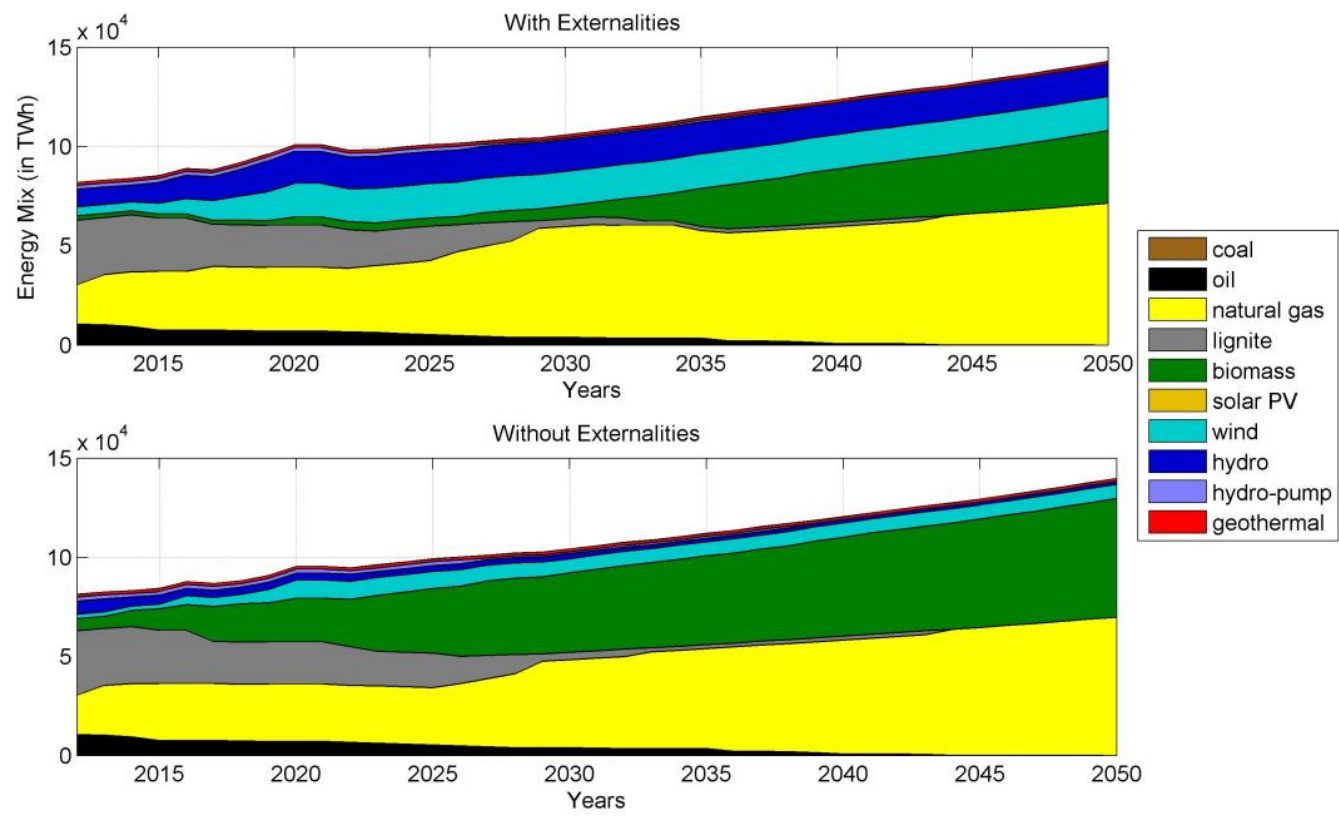

Figure 5. Energy mix - High $\mathrm{CO}_{2}$ prices scenario

Figure 6 presents the electricity generating cost of all fuel sources for the years 2012, 2030 and 2050, for the low $\mathrm{CO}_{2}$ price scenario. The external cost is depicted as an additional cost. Externalities are a significant proportion of the total generating cost for all conventional fuel sources, with the exception of natural gas as well as for biomass and geothermal energy.

One may also notice that the total generating cost has an increasing trend in the future for conventional energy sources, primarily due to the expected increase in fuel cost, whereas it decreases for most of the RES, due to their high learning rates. The exceptions to this finding are geothermal and hydro-power plants that have very stable generating cost during the 38 year-long time-period, due to the low learning rates. Also biomass has stable generating cost, but for a different reason: biomass as a fuel source is expected to become more expensive in the future; therefore, the positive effect of its high learning rate is cancelled. These findings are valid either with or without the externalities. 


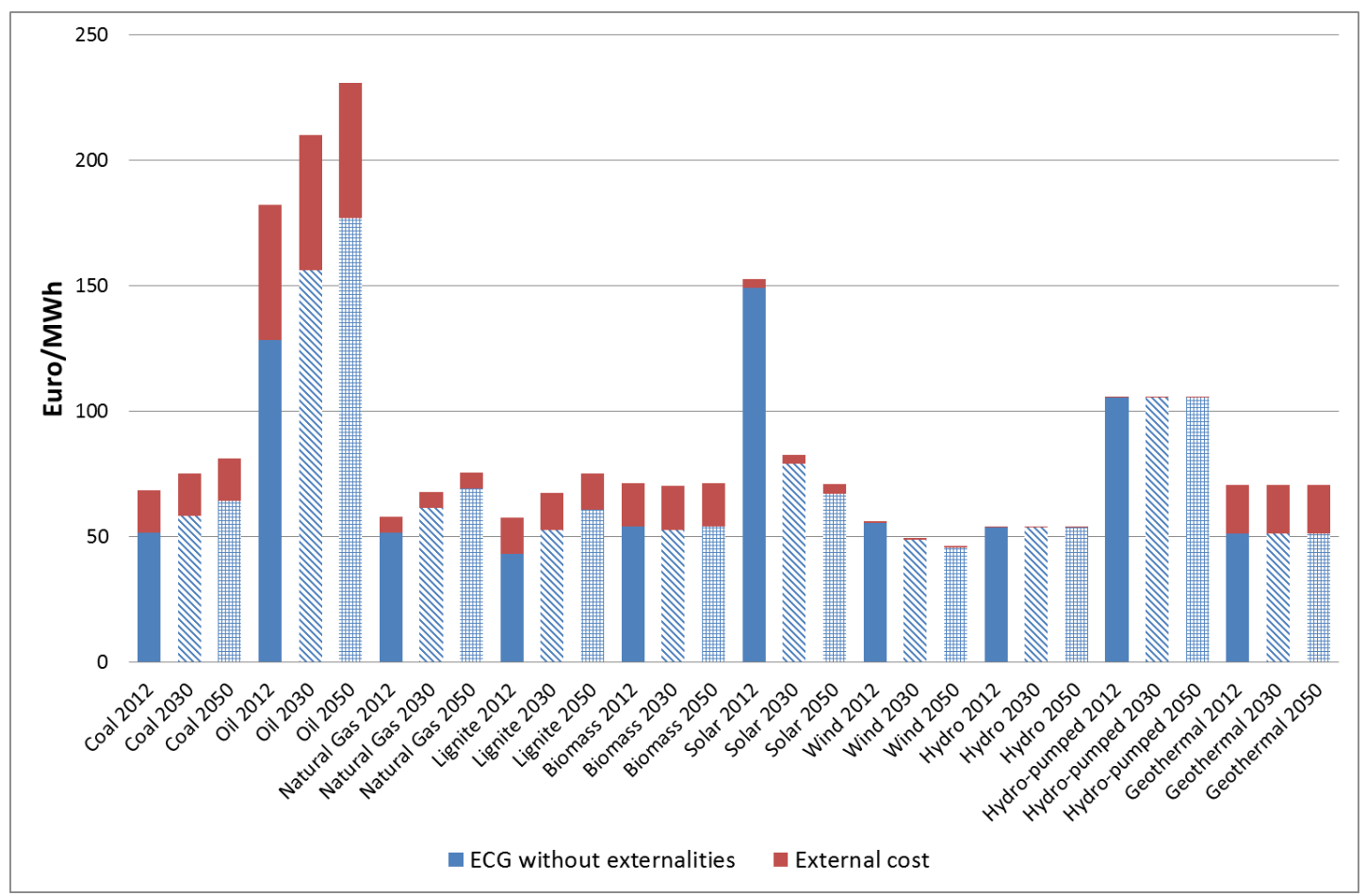

Figure 6. Electricity generating cost and external cost - $\mathrm{Low} \mathrm{CO}_{2}$ price scenario

There are several electricity generation technologies that have almost the same electricity generating cost at a certain time period. For example, in the year 2030, lignite, geothermal, biomass and hydro-power are expected to have very similar electricity generating cost values before externalities. However, if the external cost is included, one can easily see that the related costs are clearly diversified. Therefore, in some cases external cost may be the decisive factor for choosing one technology/fuel source against another. Another remark is that solar PV energy does not seem to be cost-competitive compared to most of the other RES before the year 2050, despite its high learning rate. Finally, externalities cost for wind and hydro-power is extremely low, whereas other RES sources, such as biomass and geothermal, have comparable or higher externalities cost than some of the conventional fuel sources (e.g. natural gas). 
The RES penetration in the yearly electricity generation is presented in Figure 7. One primary finding is that including the externalities in the electricity generation cost calculations leads to lower RES penetration, irrespective of the $\mathrm{CO}_{2}$ price. Externalities also defer the point of increased RES penetration further in the future for the same $\mathrm{CO}_{2}$ price scenario; this is primarily a result of biomass being significantly more expensive when externalities are accounted for. In all scenarios, the minimum RES penetration target of $40 \%$ is achieved by the year 2020, but after this year the penetration is diversified for each scenario. If $\mathrm{CO}_{2}$ prices are low and the external cost is included, the penetration remains at its lower limit of $40 \%$. In all other scenarios, the penetration eventually reaches the upper limit of $50 \%$, which means that after a certain period of time there is at least one RES with available capacity that has lower generating cost than the conventional fuel sources. Especially for the scenario without externalities and high $\mathrm{CO}_{2}$ prices, this point is achieved already by the year 2022 .

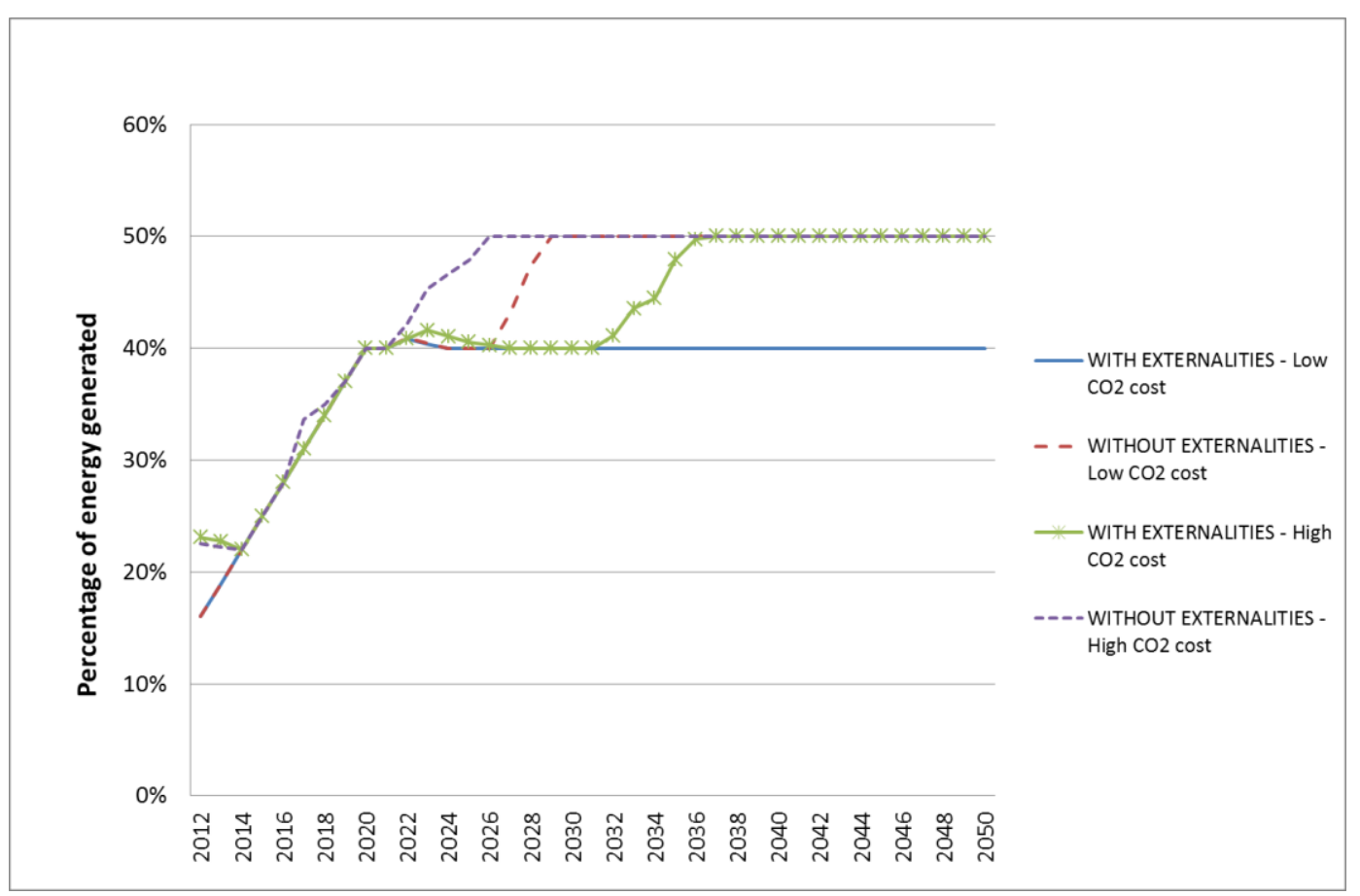

Figure 7. RES penetration 
Figures 8 and 9 present the percentage of the maximum potential capacity used each year for all the RES sources for which an upper capacity level has been identified, namely geothermal, hydro-power and wind, separately for the two $\mathrm{CO}_{2}$ price scenarios. The findings are of the same nature for both $\mathrm{CO}_{2}$ price scenarios. Firstly, geothermal capacity is fully used from the beginning, as the available capacity is very limited. It can also be concluded that wind and hydro-power are extensively used during the first years of the period examined, in order to reach the ambitious RES penetration target of $40 \%$. If external cost is included, wind and hydro-power capacities are fully used around the year 2020, whereas for the scenarios without externalities there is significant potential left unused. The latter may be explained by the higher biomass usage (as can be seen also in Figures 4 and 5), which is preferred only when externalities are not accounted for, as the related cost for biomass is significantly higher than for wind or hydro-power.

Wind energy appears to be reaching a maximum penetration level in the year 2020, if externalities are not included in the cost estimations. After the year 2020, its penetration level is reduced, due to increased use of new biomass generating capacity, and only after the year 2045 its penetration level is increased again, though just in the case of low $\mathrm{CO}_{2}$ price.

Hydro-power, in particular, presents a very diverse behaviour: while its capacity is fully and promptly used in the scenarios with externalities, its use is continuously reduced to very low levels in the scenarios without externalities. The underlying reason for this phenomenon is again the relatively lower electricity generation cost of biomass in the scenarios without externalities, which promotes its use over hydro-power primarily and wind secondarily. 
The main effect of the higher $\mathrm{CO}_{2}$ price is that wind and hydro-power capacities are fully exploited at a later point in time if externalities are included. If externalities are not included, higher $\mathrm{CO}_{2}$ price leads to significantly lower wind penetration level than with low $\mathrm{CO}_{2}$ price. Geothermal energy does not seem to be affected and is fully used early on in all scenarios.

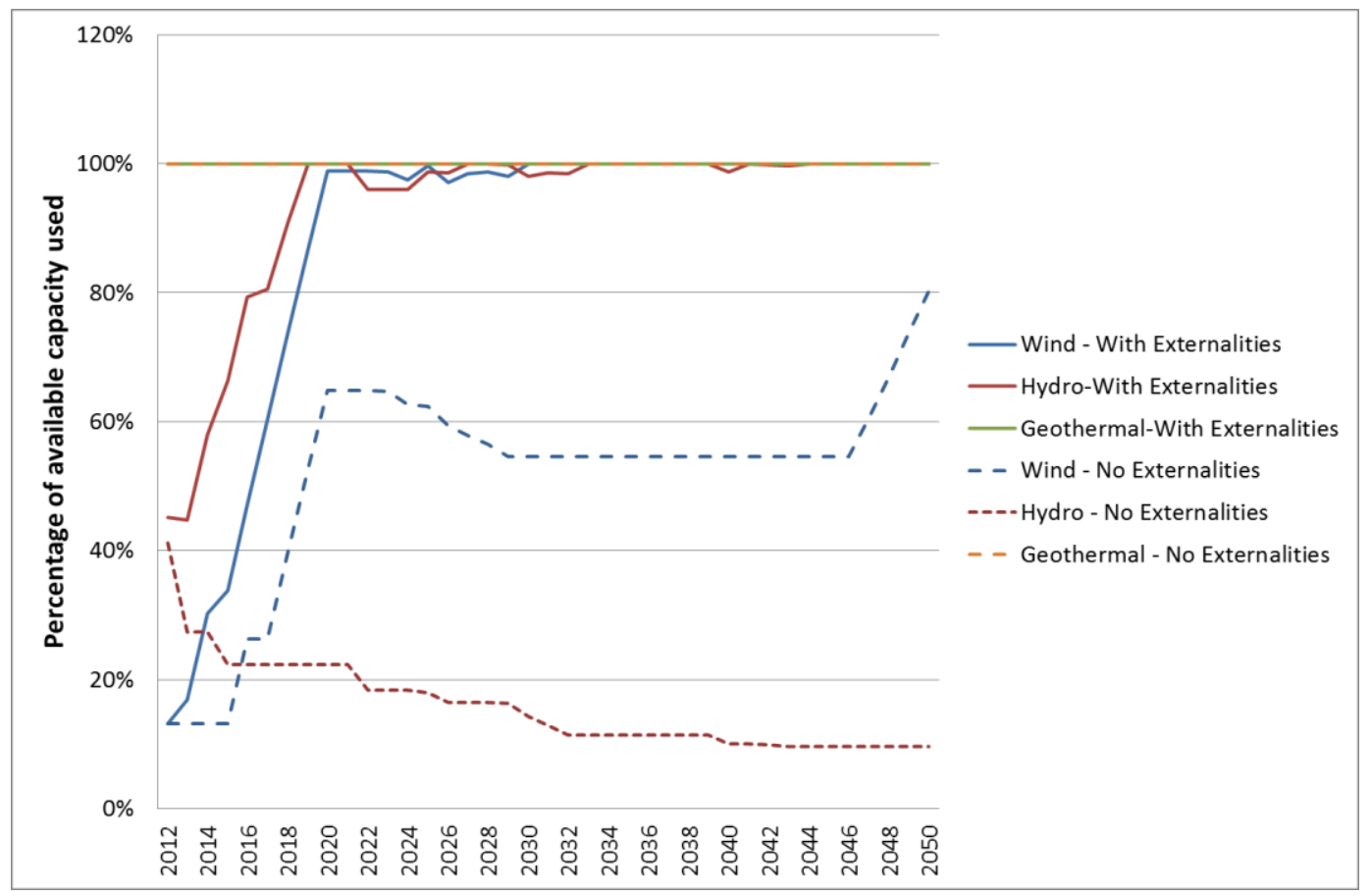

Figure 8. RES available capacity used - for $\mathrm{Low} \mathrm{CO}_{2}$ prices 


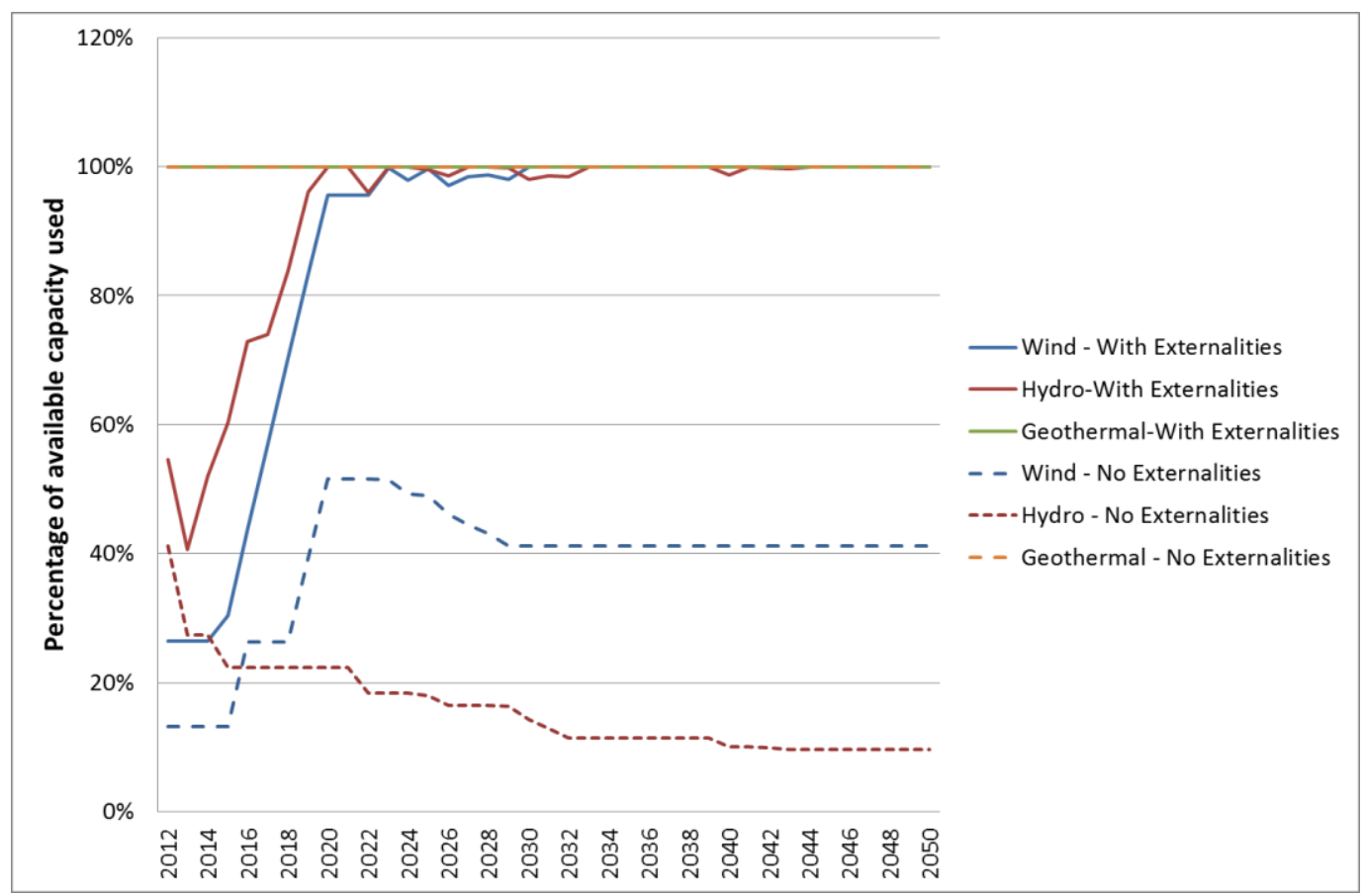

Figure 9. RES available capacity used - for High $\mathrm{CO}_{2}$ prices

In the case of small fluctuations from year to year (apparent in the cases of wind and hydro-power in the scenarios with externalities, in both Figures 8 and 9), the explanation is that old power plants reach their life limit and are decommissioned without being immediately replaced by new ones.

\section{SENSITIVITY ANALYSIS}

The analysis presented in this work is based on several assumptions over the values of inherently volatile parameters, such as the future fuel cost, and other parameters, whose future evolution pattern is subject to some level of uncertainty, as in the case of learning rate of each technology. Furthermore, parameters such as the investment and O\&M costs can be site-specific, and the externalities presented are calculated based on a series of assumptions used in the LCA methodology. For all the above reasons, it is considered essential to perform a sensitivity analysis of the model results when changing the above critical parameters. As the model 
potentially leads to a different solution for every change in the parameter values, the basis of comparison was chosen to be the cumulative amount of energy generated from each fuel source during the period 2012-2050. The Figures 10 to 13 present the change of the percentage in the energy generated from each fuel source, compared to the base-case scenario. For example, in Figure 10, natural gas increases its energy contribution by $2.93 \%$ when external cost increases by $30 \%$, which means that its contribution to the total energy generated is $46.83 \%$ as compared to the $43.9 \%$ of the base case. Due to the large number of results and the difficulty to present them in a concise and legible manner, only the sensitivity analysis for increasing the parameter values by $30 \%$ is presented.

Figure 10 shows that if external cost is increased by $30 \%$ and $\mathrm{CO}_{2}$ price is low, natural gas is significantly increasing its contribution to energy generation by almost 3\%, displacing an almost equal amount of energy generated by lignite. Additionally, wind increases its energy contribution by $0.3 \%$ at the expense of biomass. If $\mathrm{CO}_{2}$ price is high, increasing the external cost leads to displacing a significant amount of biomass energy by natural gas. In all cases, natural gas seems to benefit by an increase of the external cost, as its related cost is relatively low. 


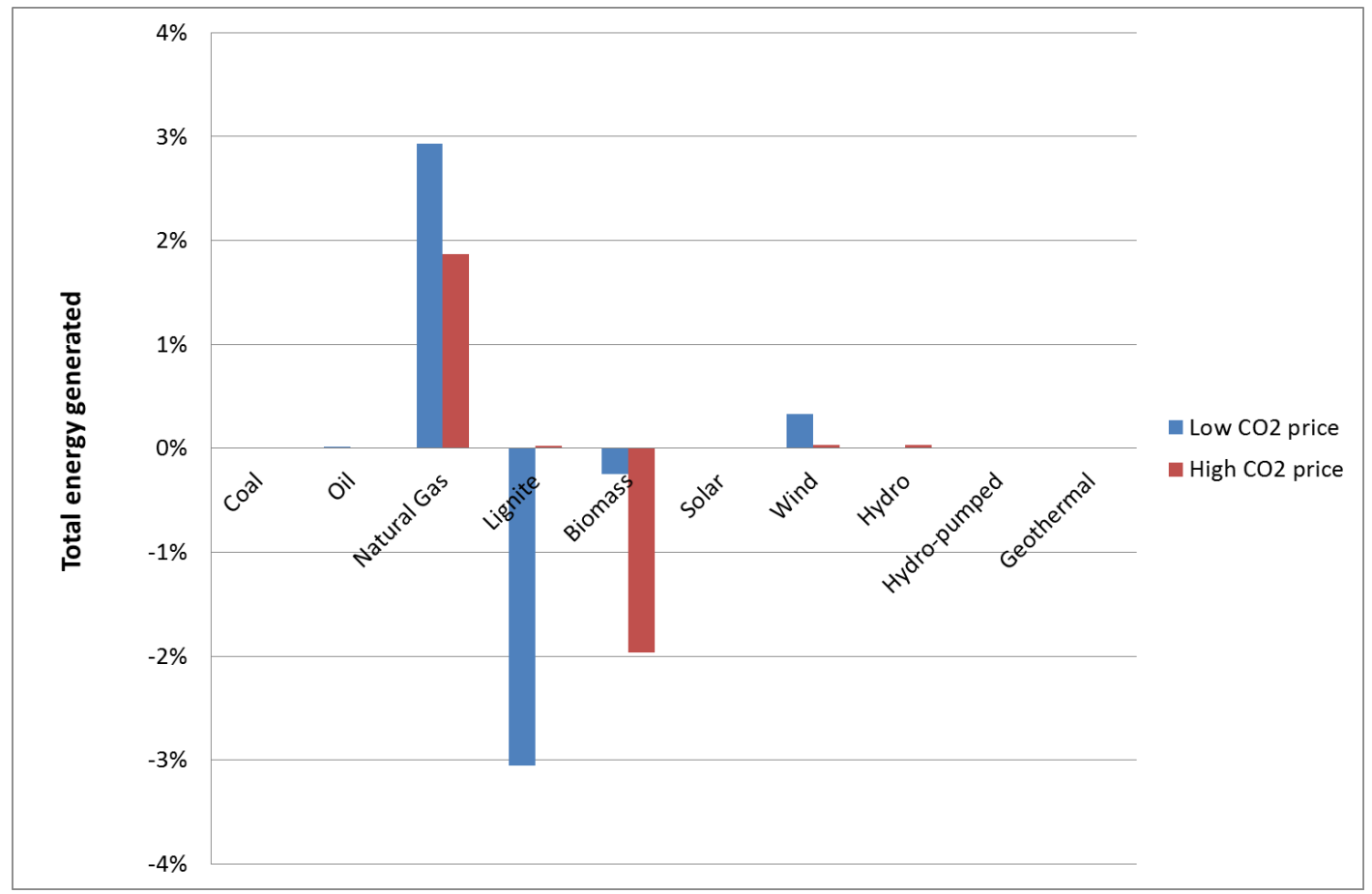

Figure 10. Sensitivity analysis - increase of external cost by $\mathbf{3 0 \%}$

It is very interesting to examine the effect of changing the fuel cost, as this is a parameter with very significant volatility (see Figure 11). In the case of low $\mathrm{CO}_{2}$ price, natural gas increases its contribution by about $1 \%$, displacing lignite, and hydro-power is displacing wind. If $\mathrm{CO}_{2}$ has high price, then a significant amount of natural gas-generated energy is displaced by RES, mainly biomass and wind, and secondarily hydro-power. Therefore one may conclude that natural gas remains a cost-competitive generating option even if fuel prices increase by $30 \%$, but only if the $\mathrm{CO}_{2}$ prices remain low. 


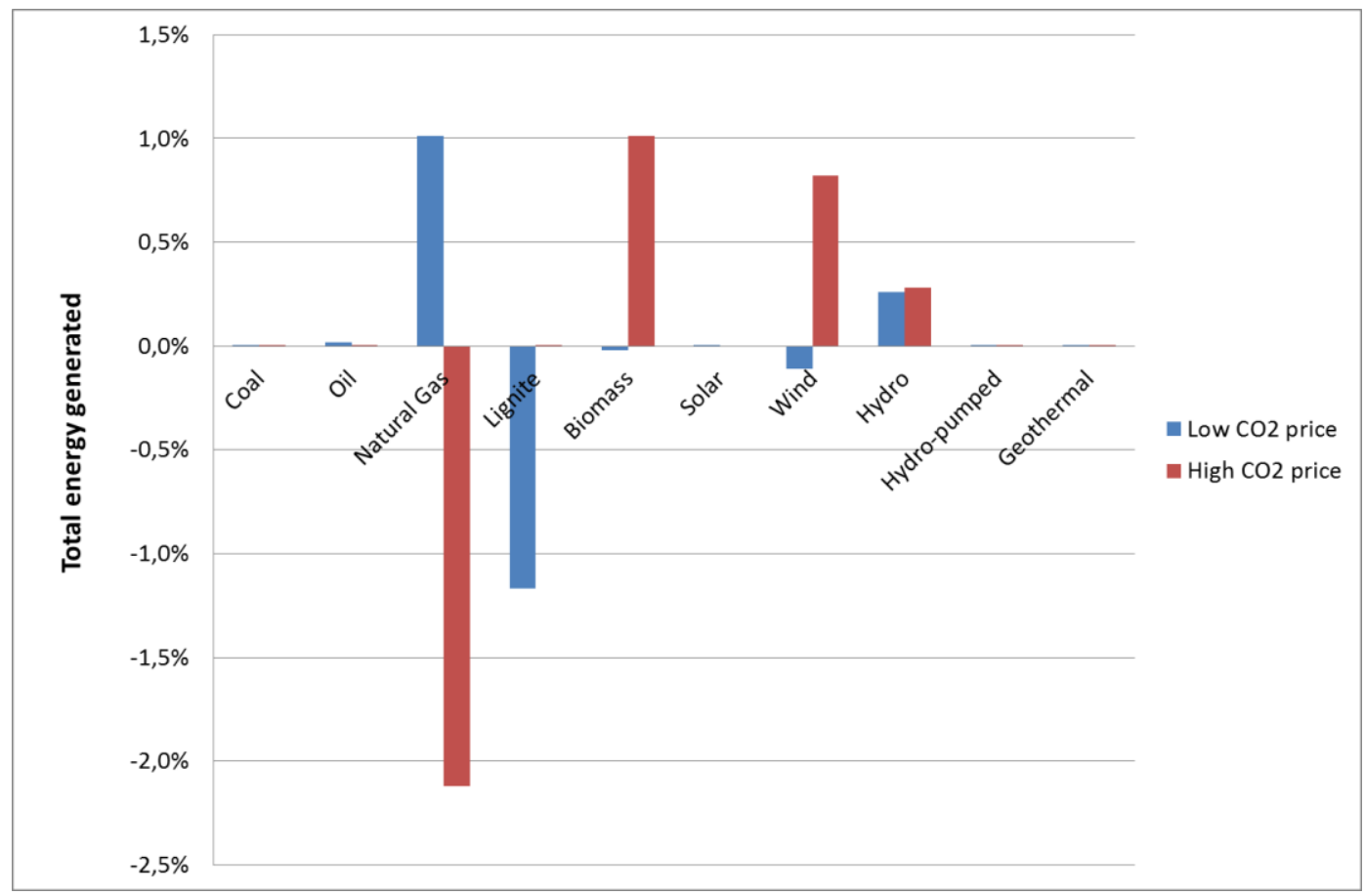

Figure 11. Sensitivity analysis - increase of fuel cost by $30 \%$

A potential increase in the investment and the O\&M cost by $30 \%$ leads to minor changes if $\mathrm{CO}_{2}$ prices are low (see Figure 12). The main effect is that an amount of hydro-power is replaced by biomass and a small fraction of wind power. For the high $\mathrm{CO}_{2}$ price scenario, a significant amount of natural gas, biomass and hydro-power is replaced by lignite (in total about $5 \%$ of the total energy). This is a result of a single lignite power plant of $840 \mathrm{MW}$ capacity ordered during the first year of the analysis and which remains operational for 40 years. 


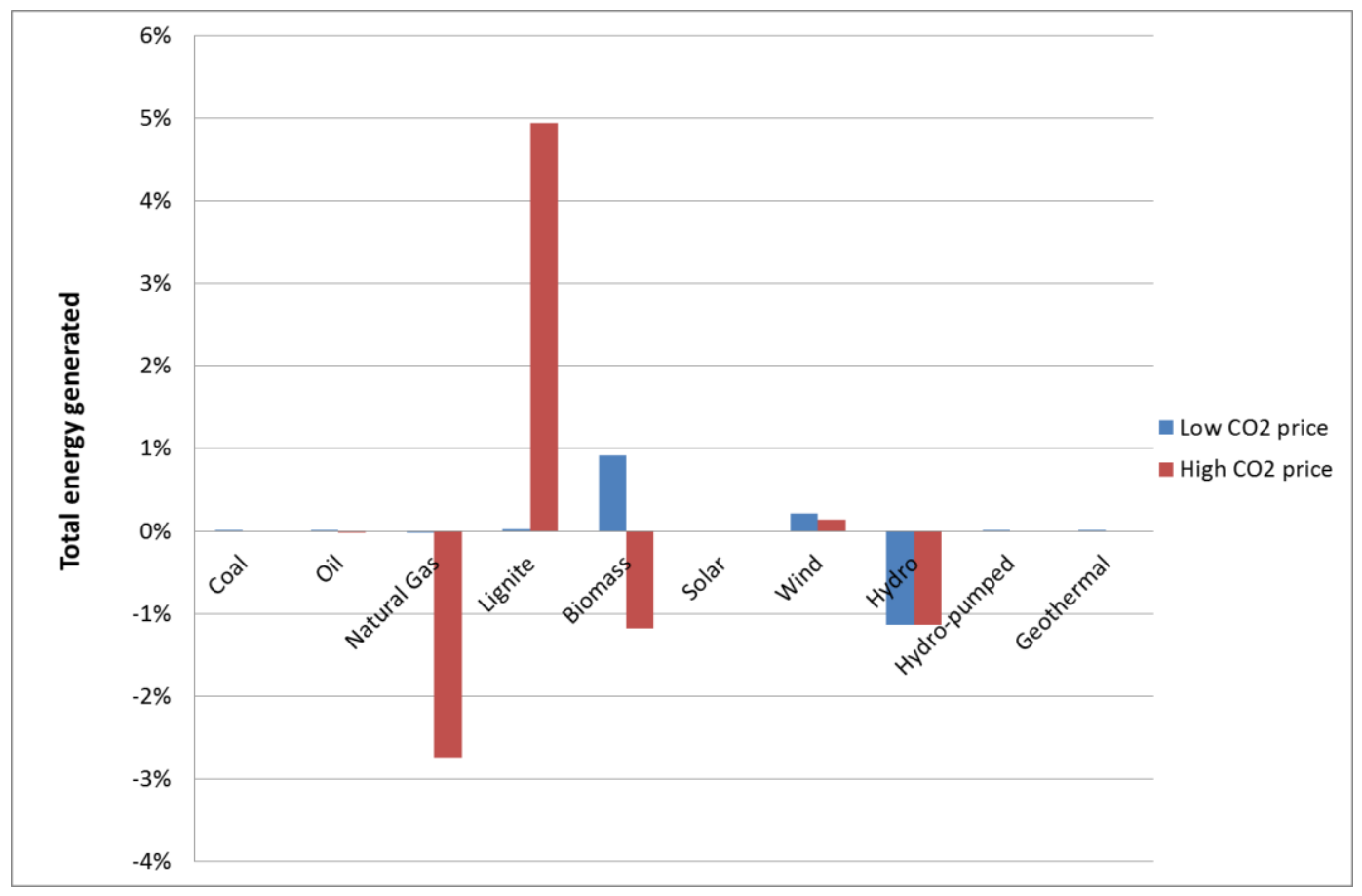

Figure 12. Sensitivity analysis - increase of investment and O\&M cost by $30 \%$

RES have been characterised by high learning rates up to now. Under the base case scenario it has been assumed that the learning rates found in the literature will remain fixed during the period of the analysis. If however, technological advances lead to increased learning rates by $30 \%$, the energy sources to take advantage of this are, as expected, the ones with the higher learning rates (see Figure 13). Therefore, under the low $\mathrm{CO}_{2}$ price scenario, solar PV energy becomes cost-competitive, generating about $0.87 \%$ of the total energy and displacing mainly biomass-generated energy and smaller amounts of hydropower. Wind also increases its contribution by about $0.2 \%$. In the scenario of high $\mathrm{CO}_{2}$ price solar PV is also introduced, generating about $0.65 \%$ of the total energy, while wind increases its contribution by $0.2 \%$, at the expense of mainly natural gas and secondarily hydro-power. The interesting conclusion is that solar 
PV energy becomes cost-competitive and is introduced in the electricity generation mix only if the learning rates prove to be $30 \%$ higher than they have been up to now.

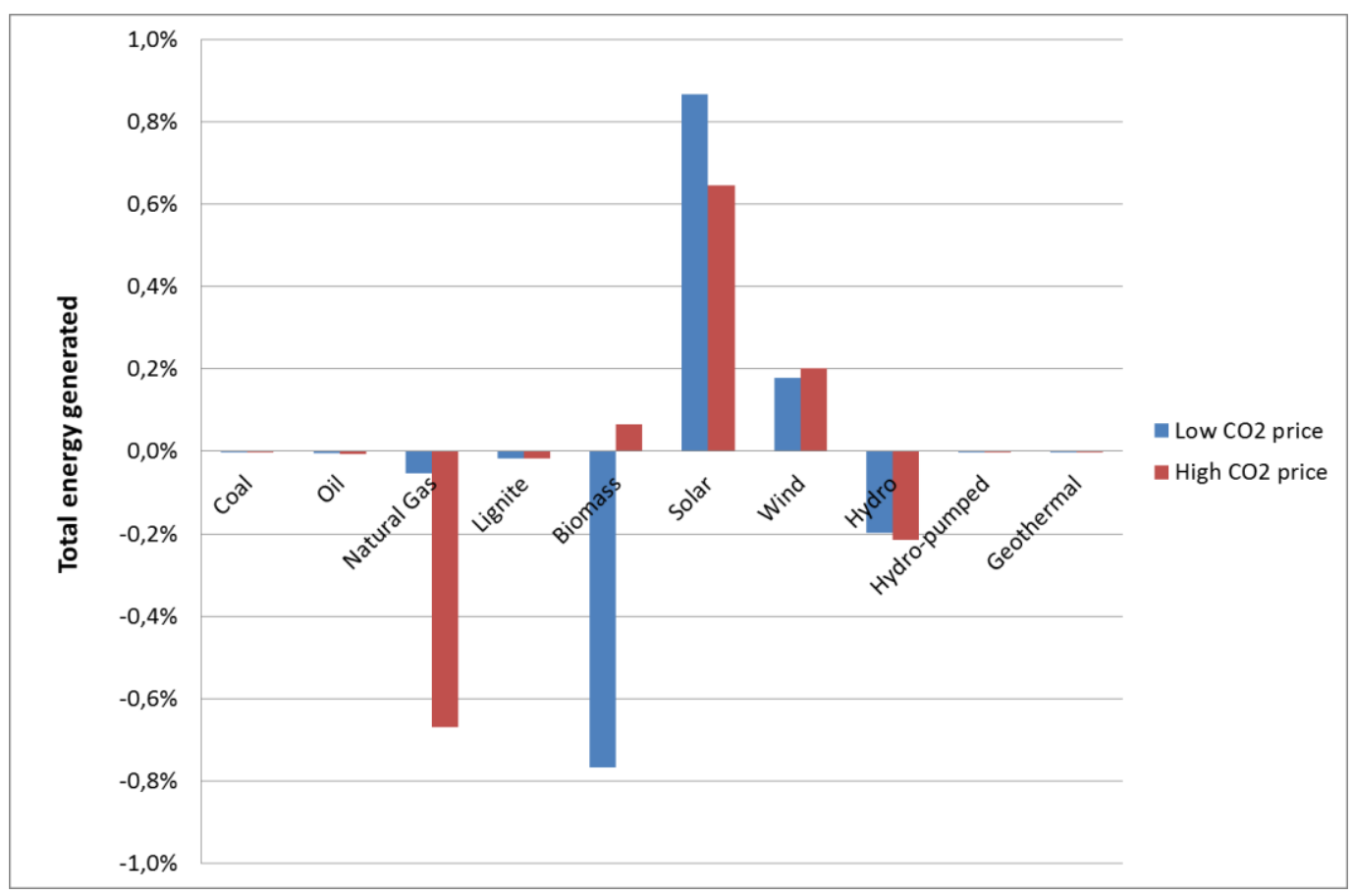

Figure 13. Sensitivity analysis - increase of learning rates by $30 \%$

\section{CONCLUSIONS}

In this work, the effect of the external cost on the strategic decision of future electricity generating mix for the years $2012-2050$ has been examined. The analysis has been performed using a linear programming model for the yearly decisions of which electricity generation source should be used to minimise the electricity generation cost. The external cost has been calculated using the Life Cycle Assessment methodology. More specifically, the life cycle inventory concept has been used in order to quantify the atmospheric emissions associated with each power generation technology under examination, while the calculation of the external cost was based on the 'impact pathway' methodology which has been developed in the series of ExternE projects, and is further improved within 
NEEDS and other related on-going projects. All energy systems have been described on a "cradle to grave" basis, i.e. the construction and operation in each stage (e.g. transportation, electricity generation) have been examined. As regards the LCA systems of the thermal power plants, these were more complicated than the ones of RES plants because in the first ones, apart from the plant construction, the LCA system has to take into consideration the fuel supply chain as well.

The necessity of the LCA incorporation in the model stems from the fact that it is the basic unambiguous scientific tool for the assessment of the environmental performance of the options under examination: since there is a number of power generation technologies (e.g. those based on RES) with almost zero environmental externalities during the electricity generation phase but with rather considerable ones during the other stages of their life-cycle, using this methodology, decreases the uncertainty of the analysis and improves the reliability of the results and, thus, of the decision making. Moreover, the integration of the LCA framework in such a model seems to be a considerably innovative approach in this kind of analyses that is carried out for the first time, illustrating the novelty of the present research.

The analysis performed has led to several interesting results. Firstly, most of the new generating capacity until the year 2020 should be renewable, in order to reach the RES penetration target of $40 \%$. The RES penetration is increased further in most scenarios examined, and this phenomenon is observed at an earlier point in time when $\mathrm{CO}_{2}$ prices are higher, which means that some RES technologies become more cost-competitive than conventional fuel sources. Furthermore, it has been found that natural gas is in most cases the only conventional fuel technology chosen. As far as the RES are concerned, the main 
preference is given to biomass and wind. If externalities are taken into consideration though, wind energy increases its share in energy generation and hydroelectric energy generation becomes cost-efficient, replacing significant amounts of biomass-generated energy. External cost has been found to be a significant percentage of the total electricity generation cost for some energy sources, therefore significantly changing the ranking order of costcompetitiveness for the energy sources examined. Finally, the electricity generating cost using conventional fuel sources is expected to increase in the future, whereas the RES present a mixed picture: some significantly reduce their generating cost (wind, solar PV) while others are characterized by relatively fixed cost in time. The main reasons for this are the expected increase in conventional fuel and biomass prices and the high learning rate of some of the RES technologies.

Due to the uncertainty characterizing several of the parameters used for the analysis, a sensitivity analysis of the results has been performed for the most critical ones. One of the most important findings is that natural gas increases its contribution to the total energy generation when external cost is increased. In the case of increase of the fuel cost, natural gas-generated energy increases for low $\mathrm{CO}_{2}$ prices, whereas biomass-generated energy increases for high $\mathrm{CO}_{2}$ prices. Finally, if the learning rates of the technologies prove to be higher in the future than they have been up to now, solar PV energy is expected to be introduced in the generation mix as a cost-efficient electricity generation technology. 


\section{Acknowledgements}

The authors would like to express their appreciation to the anonymous reviewers for their insightful remarks.

\section{References}

Ackerman, F., Stanton, E.A., 2008. The Cost of Climate Change - What we'll pay if Global Warming continues unchecked. Natural Resources Defence Council, New York.

Akkemik, K.A., 2009. Cost function estimates, scale economies and technological progress in the Turkish electricity generation sector. Energy Policy, 37 (1), 204-213.

Atakhanova, Z., Howie, P., 2007. Electricity demand in Kazakhstan. Energy Policy, 35, 3729 3743.

Awerbuch, S., 2006. Portfolio-Based Electricity Generation Planning: Policy Implications for Renewables and Energy Security. Mitigation and Adaptation Strategies for Global Change, 11, 693-710.

Awerbuch, S., Berger, M., 2003. Energy Security and Diversity in the EU: A Mean-Variance

Portfolio Approach. International Energy Agency, Paris.

Babbitt, C.W., Lindner, A.S., 2005. A life cycle inventory of coal used for electricity production in Florida. Journal of Cleaner Production, 13, 903-912.

Bagnall, A.J., 2004. A multi-agent model of the UK market in electricity generation, in: Bull, L. (Ed), Applications of learning classifier systems. Springer-Verlag, Germany, pp.167-181.

Bar-Lev, D., Katz S., 1976. A portfolio approach to fossil fuel procurement in the electric utility industry. Journal of Finance, 31, 933-947.

Bazilian, M., Roques, F., 2008. Analytic Methods for Energy Diversity and Security. Applications of Mean Variance Portfolio Theory. A tribute to Shimon Awerbuch. Elsevier, London.

Biska, A.G., Oikonomou, N., 2006. Environmental consideration of ready-mixed concrete production. Technika Chronika Journal I, 3, 35-48.

Bozicevic Vrhovcak, M., Tomsic, Z., Debrecin, N., 2005. External costs of electricity production: case study Croatia. Energy Policy, 33 (11), 1385-1395. 
Cai, W., Wang, C., Wang, K., Zhang, Y., Chen, J., 2007. Scenario analysis on CO2 emissions reduction potential in China's electricity sector. Energy Policy, 35, 6445-6456.

Caralis, G., Perivolaris, Y., Rados, K., Zervos, A., 2008. On the effect of spatial dispersion of wind power plants on the wind energy capacity credit in Greece. Environmental Research Letters, 3 (1), 1-13.

Chaaban, F.B., Mezher, T., Ouwayjan, M., 2004. Options for emissions reduction from power plants: an economic evaluation. Electrical Power and Energy Systems, 26, 57-63.

Ciscar, J.-C., 2009. Climate Change Impacts in Europe: Final Report of the PESETA Research Project. European Commission, Joint Research Centre, Institute for Prospective Technological Studies, Institute for Environment and Sustainability, Luxembourg.

Climate Economics Chair, 2012. Press Release - December 19th 2011: European CO2 emission trading system - Publication of CO2 price forecast (ZEPHYR-Flex model), http://www.chaireeconomieduclimat.org/?page_id=2259\&lang=en, accessed 08/2012.

Curran, M.A., 2006. Life Cycle Assessment: Principles and Practice, EPA/600/R-06/060. U.S. Environmental Protection Agency, Cincinnati.

Dilaver, Z., Hunt, L.C., 2011. Modelling and forecasting Turkish residential electricity demand. Energy Policy, 39, 3117-3127.

Dinca, C., Rousseaux, P., Badea, A., 2007. A life cycle impact of the natural gas used in energy sector in Romania. Journal of Cleaner Production, 15, 1451-1462.

Dones, R., Gantner, U., Hirschberg, S., 1999. Greenhouse gas total emissions from current and future electricity and heat supply systems, in: Eliasson, B., Riemer, P., Wokaun, A. (Eds.), Proceedings of 4th International Conference on Greenhouse Gas Control, Technologies (GHGT-4). Pergamon, Amsterdam, pp. 891-896.

Dones, R., Bauer, C, Bolliger, R., Burger, B., Faist-Emmenegger, M., Frischknecht, R., Heck, T., Jungbluth, N., Roder, A., Tuchschmid, M., 2007. Life Cycle Inventories of Energy Systems: Results for Current Systems in Switzerland and other UCTE Countries, Ecoinvent report No. 5. Paul Scherrer Institut Villigen, Swiss Centre for Life Cycle Inventories, Dübendorf.

Fankhauser, S., Tol, R.S.J., 1996. Climate change costs - Recent advancements in the economic assessment. Energy Policy, 24(7), 665-673. 
Fortin, I., Fuss, S., Hlouskova, J., Khabarov, N., Obersteiner, M., Szolgayova, J., 2008. An Integrated CVaR and Real Options Approach to Investments in the Energy Sector. Journal of Energy Markets, 1, 61-85.

Fritsche, U., Rausch, L., 2009, Life Cycle Analysis of GHG and Air Pollutant Emissions from Renewable and Conventional Electricity, Heating, and Transport Fuel Options in the EU until 2030, ETC/ACC Technical Paper 2009/18, The European Topic Centre on Air and Climate Change (ETC/ACC), Bilthoven.

Fruergaard, T., Hyks, J., Astrup, T., 2010. Life-cycle assessment of selected management options for air pollution control residues from waste incineration. Science of the Total Environment, 408, 4672-4680.

Gagnon, L., Belanger, C., Uchiyama, Y., 2002. Life-cycle assessment of electricity generation options: The status of research in the year 2001. Energy Policy, 30, 1267-1278.

Georgakellos, D.A., 2005. Evaluation of life cycle inventory results using critical volume aggregation and polygon-based interpretation. Journal of Cleaner Production, 13, 567582.

Georgakellos, D.A., 2006. The use of the LCA polygon framework in waste management. Management of Environmental Quality: An International Journal, 17(4), 490-507.

Georgakellos, D.A., 2010. Impact of a possible environmental externalities internalization on energy prices: The case of greenhouse gases from the Greek electricity sector. Energy Economics, 32 (1), 202-209.

Georgakellos, D.A., 2012. Climate change external cost appraisal of electricity generation systems from a life cycle perspective: The case of Greece. Journal of Cleaner Production, 32, 124140.

Gökçek, M., Genç, M., 2009. Evaluation of electricity generation and energy cost of wind energy conversion systems (WECSs) in Central Turkey. Applied Energy, 86, 2731-2739.

Graebig, M., Bringezu, S., Fenner, R., 2010. Comparative analysis of environmental impacts of maize-biogas and photovoltaics on a land use basis. Solar Energy, 84, 1255-1263.

Graedel, T.E., Allenby, B.R., 2010. Industrial Ecology and Sustainable Engineering. Pearson Int. Ed., Upper Saddle River, NJ. 
Grover, R.B., Chandra, S., 2006. Scenario for growth of electricity in India. Energy Policy, 34, 2834-2847.

Guinée, J.B., Huppes, G., Heijungs, R., 2001. Developing an LCA guide for decision support. Environmental Management and Health, 12(3), 301-311.

Han, X., Naeher, L.P., 2006. A review of traffic-related air pollution exposure assessment studies in the developing world. Environment International, 32, 106 - 120.

Hassan, O.A.B., 2003. A value-focused thinking approach for environmental management of buildings construction. Journal of Environmental Assessment Policy and Management, $5(2), 247-261$.

Hellenic Republic, 2006. Country profile: Greece - National Reporting to the Fourteenth \& Fifteenth Sessions of the Commission for Sustainable Development of the United Nations (UNCSD 14 - UNCSD 15). Ministry for the Environment, Physical Planning and Public Works, Athens.

Hitz, S., Smith, J., 2004. Estimating global impacts from climate change. Global Environmental Change, 14, 201-218.

Hondo, H., 2005. Life cycle GHG emission analysis of power generation systems: Japanese case. Energy, 30, 2042-2056.

Höjer, M., Ahlroth, S., Dreborg, K.-H., Ekvall, T., Finnveden, G., Hjelm, O., Hochschorner, E., Nilsson, M., Palm, V., 2008. Scenarios in selected tools for environmental systems analysis. Journal of Cleaner Production, 16, 1958-1970.

Huybrechts, D., Berloznik, R., Wouters, G., Marion, J.-Y., Valenduc, G., Vendramin, P., 1996. The role of ecobalances in environmental decision-making. Journal of Cleaner Production, 4(2), 111-119.

IEA - International Energy Agency, 2005. Projected Cost of Generating Electricity - 2005 Update, NEA-IEA-OECD, Paris.

IEA - International Energy Agency, 2006. Wind Energy: 2006 Annual Report. OECD/IEA, Paris. IEA - International Energy Agency, 2010. Projected Costs of Generating Electricity - 2010 Edition, NEA-IEA-OECD, Paris. 
Ison, E., Miller, A., 2000. The use of LCA to introduce life-cycle thinking into decision-making for the purchase of medical devices in the NHS. Journal of Environmental Assessment Policy and Management, 2(4), 453-476.

Jaber, J.O., Al-Sarkhi, A., Akash, B.A., Mohsen, M.S., 2004. Medium-range planning economics of future electrical-power generation options. Energy Policy, 32 (3), 357-366.

Jing, Y.-Y., Bai, H., Wang, J.-J., Liu, L., 2012. Life cycle assessment of a solar combined cooling heating and power system in different operation strategies. Applied Energy, 92, 843-853.

Kaldellis, J.K., Zafirakis, D., Kondili, E., 2010. Energy pay-back period analysis of stand-alone photovoltaic systems. Renewable Energy, 35, 1444-1454.

Kellenberger, D., Althaus, H.-J., Jungbluth, N., Kunniger, T., Lehmann, M., Thalmann, P., 2007. Life Cycle Inventories of Building Products. Final report ecoinvent Data v2.0 No. 7. EMPA Dübendorf. Swiss Centre for Life Cycle Inventories, Dübendorf.

Korre, A., Durucan, S., 2009. Life Cycle Assessment of Aggregates, EVA025 -Final Report: Aggregates Industry Life Cycle Assessment Model: Modelling Tools and Case Studies. Waste and Resources Action Programme, Oxon.

Krey, V., Martinsen, D., Wagner, H.J., 2007. Effects of stochastic energy prices on long-term energy-economic scenarios. Energy, 32 (12), 2340-2349.

Kucukali, S., Baris, K., 2010. Turkey's short-term gross annual electricity demand forecast by fuzzy logic approach. Energy Policy, 38, 2438-2445.

Kudelko, M., 2006. Internalisation of external costs in the Polish power generation sector: A partial equilibrium model. Energy Policy, 34 (18), 3409-3422.

Kumbaroglu, G., Madlener, R., Demirel, M., 2008. A real options evaluation model for the diffusion prospects of new renewable power generation technologies. Energy Economics, 30, 1882-1908.

Lady, G.M, 2010. Evaluating long term forecasts. Energy Economics, 32, 450-457.

Liu, T., Xu, G., Cai, P., Tian, L., Huang, Q., 2011. Development forecast of renewable energy power generation in China and its influence on the GHG control strategy of the country. Renewable Energy, 36, 1284-1292. 
Liu, Y., Langer, V., Høgh-Jensen, H., Egelyng, H., 2010. Life Cycle Assessment of fossil energy use and greenhouse gas emissions in Chinese pear production. Journal of Cleaner Production, 18, 1423-1430.

Lora E.E.S, Salomon K.R, 2005. Estimate of ecological efficiency for thermal power plants in Brazil. Energy Conversion and Management, 46, 1293-1303.

Lawson, J., 2007. The Environmental Footprint of Surface Freight Transportation, Transportation Research Board Special Report 291. Lawson Economics Research, Inc, Ottawa, Canada.

Madival, S., Auras, R., Singh, S.P., Narayan, R., 2009. Assessment of the environmental profile of PLA, PET and PS clamshell containers using LCA methodology. Journal of Cleaner Production, 17, 1183-1194.

Madlener, R., Kumbaroglu, G., Ediger, V., 2005. Modelling technology adoption as an irreversible investment under uncertainty: the case of the Turkish electricity supply industry. Energy Economics, 27, 39-163.

Moberg, A., Finnveden, G., Johansson, J., Lind, P., 2005. Life cycle assessment of energy from solid waste - part 2: landfilling compared to other treatment methods. Journal of Cleaner Production, 13, 231-240.

Mondal, M.A.H., Boie, W., Denich, M., 2010. Future demand scenarios of Bangladesh power sector. Energy Policy, 38, 7416-7426.

Montanari, R., 2004. Environmental efficiency analysis for ENEL thermo-power plants. Journal of Cleaner Production. 12, 403-414.

Nakano, K., Hirao, M., 2011. Collaborative activity with business partners for improvement of product environmental performance using LCA. Journal of Cleaner Production, 19, 11891197.

National Observatory of Athens, 2005. Projections of GHG emissions - Policies and measures for reducing GHG emissions. NOA - Institute of Environmental Research and Sustainable Development, Athens.

NEEDS, 2009. External costs from emerging electricity generation technologies, Deliverable $\mathrm{n}^{\circ}$ 6.1 - RS1a, New Energy Externalities Developments for Sustainability. European Commission, Brussels. 
Nguyen, T.L.T., Gheewala, S.H., 2008. Fossil energy, environmental and cost performance of ethanol in Thailand. Journal of Cleaner Production, 16, 1814-1821.

Notarnicola, B., Hayashi, K., Curran, M.A., Huisingh, D., 2012. Progress in working towards a more sustainable agri-food industry. Journal of Cleaner Production, 28, 1-8.

Owen, A.D., 2006, Renewable energy: Externality costs as market barriers. Energy Policy, 34(5), $632-642$

Porat, Y., Irith, R., Turvey, R., 1997. Long-run marginal electricity generation costs in Israel. Energy Policy, 25(4), 401-411.

Pyrovolakis, A.A., Georgakellos, D.A., 2005. Life cycle assessment of electric power coming from a typical Greek petroleum power station. Technika Chronika Journal IV, 1-2, 67-80.

Rachmatullah, C., Aye, L., Fuller, R.J., 2007. Scenario planning for the electricity generation in Indonesia. Energy Policy, 35, 2352-2359.

Rafaj, P., Kypreos, S., 2007. Internalisation of external cost in the power generation sector: analysis with global multi-regional MARKAL model. Energy Policy, 35, 828-843.

Rentizelas, A.A., Tolis, A.I., Tatsiopoulos, I.P., 2012, Investment planning in electricity production under $\mathrm{CO}_{2}$ price uncertainty. International Journal of Production Economics, $140,622-629$.

Roques, F.A., Newberry, D.M., Nuttall, W.J., 2008. Fuel Mix Diversification Incentives in Liberalized Electricity Markets: A Mean-Variance Portfolio Theory Approach. Energy Economics, 30, 1831-1849.

Simshauser, P., Doan, T., Lacey, B., 2007. The Outlook for the Economic and Environmental Performance of Australia's National Electricity Market in 2030. The Electricity Journal, $20(6), 58-75$.

Steen, B., 2005. Environmental costs and benefits in life cycle costing. Management of Environmental Quality: An International Journal, 16(2), 107-118.

Tsoutsos, T., Kouloumpis, V., Zafiris, Th., Foteinis, S., 2010. Life Cycle Assessment for biodiesel production under Greek climate conditions. Journal of Cleaner Production, 18, 328-335.

Turton, H., 2008. ECLIPSE: An integrated energy-economy model for climate policy and scenario analysis. Energy, 33(12), 1754-1769. 
Vinodh, S., Rathod, G., 2009. Integration of ECQFD and LCA for sustainable product design. Journal of Cleaner Production, 18, 833-842.

Vithayasrichareon, P., MacGill, I.F. 2012. A Monte Carlo based decision-support tool for assessing generation portfolios in future carbon constrained electricity industries. Energy Policy, 41, 374-392.

Von Blottnitz, H., Curran, M.A., 2007. A review of assessments conducted on bio-ethanol as a transportation fuel from a net energy, greenhouse gas, and environmental life cycle perspective. Journal of Cleaner Production, 15, 607-619.

Weigt, H., 2009. Germany’s wind energy: The potential for fossil capacity replacement and cost saving. Applied Energy, 86(10), 1857-1863.

WSA, 2011. Methodology report - Life cycle inventory study for steel products. World Steel Association, Brussels.

Xia, Y., Zhao, Y.D., Saha, T.K., 2008. Optimal portfolio selection for generators in the electricity market. Power and Energy Society General Meeting - Conversion and Delivery of Electrical Energy in the 21st Century. IEEE, 1-7.

Zutshi, A., Sohal, A.S., 2004. Adoption and maintenance of environmental management systems. Critical success factors. Management of Environmental Quality: An International Journal, 15(4) 399-419. 


\section{Figure Captions}

Figure 1. $\mathrm{CO}_{2}$ price scenarios

Figure 2. Yearly capacity additions - Low $\mathrm{CO} 2$ prices scenario

Figure 3. Yearly capacity additions - High $\mathrm{CO} 2$ prices scenario

Figure 4. Energy mix - Low CO2 prices scenario

Figure 5. Energy mix - High CO2 prices scenario

Figure 6. Electricity generating cost and external cost - Low CO2 price scenario

Figure 7. RES penetration

Figure 8. RES available capacity used - for Low $\mathrm{CO} 2$ prices

Figure 9. RES available capacity used - for High $\mathrm{CO} 2$ prices

Figure 10. Sensitivity analysis - increase of external cost by $30 \%$

Figure 11 . Sensitivity analysis - increase of fuel cost by $30 \%$

Figure 12. Sensitivity analysis - increase of investment and O\&M cost by $30 \%$

Figure 13. Sensitivity analysis - increase of learning rates by $30 \%$ 
Table 1. Unit damage costs for air pollutants per impact category ${ }^{\text {a }}$

\begin{tabular}{|c|c|c|c|c|c|c|}
\hline \multirow[b]{2}{*}{ Pollutant } & \multirow[b]{2}{*}{ Unit } & \multicolumn{5}{|c|}{ Impact } \\
\hline & & health & biodiversity & crop yield & $\begin{array}{l}\text { material } \\
\text { damage }\end{array}$ & $\begin{array}{l}\text { climate } \\
\text { change }\end{array}$ \\
\hline NMVOC & $€ / \mathrm{t}$ & 941 & -70 & 189 & 0 & 0 \\
\hline NOx & $€ / \mathrm{t}$ & 5,722 & 942 & 328 & 71 & 0 \\
\hline PPM (2.5-10 $\mu \mathrm{m})$ & $€ / \mathrm{t}$ & 1,327 & 0 & 0 & 0 & 0 \\
\hline $\operatorname{PPM}(<2.5 \mu \mathrm{m})$ & $€ / \mathrm{t}$ & 24,570 & 0 & 0 & 0 & 0 \\
\hline $\mathrm{SO}_{2}$ & $€ / \mathrm{t}$ & 6,348 & 184 & -38 & 259 & 0 \\
\hline $\mathrm{CO}_{2}$ & $€ / \mathrm{t}$ & 0 & 0 & 0 & 0 & 7 \\
\hline
\end{tabular}

a (NEEDS, 2009) 
Table 2. Life cycle air pollutants emission factors of various electricity generation technologies

\begin{tabular}{|c|c|c|c|c|c|c|c|c|c|c|}
\hline \multirow{2}{*}{ Pollutant } & \multirow{2}{*}{ Unit } & \multicolumn{9}{|c|}{ Fuel / RES Type } \\
\hline & & Lignite $^{\text {a }}$ & Hard Coal $^{\text {a }}$ & Natural Gas ${ }^{a}$ & Oil $^{b}$ & Biomass $^{\text {a }}$ & Hydro $^{c}$ & $\mathbf{P V}^{\mathbf{a}}$ & Wind $^{d}$ & Geothermal $^{\mathrm{e}}$ \\
\hline NMVOC & $\mathrm{kg} / \mathrm{kWh}$ & $2.36 \mathrm{E}-05$ & $5.94 \mathrm{E}-05$ & $1.01 \mathrm{E}-04$ & $3.45 \mathrm{E}-05$ & $2.22 \mathrm{E}-04$ & $1.17 \mathrm{E}-06$ & $7.09 \mathrm{E}-05$ & $8.05 \mathrm{E}-06$ & $0.00 \mathrm{E}+00$ \\
\hline NOx & $\mathrm{kg} / \mathrm{kWh}$ & $7.38 \mathrm{E}-04$ & 8.07E-04 & $3.09 \mathrm{E}-04$ & $6.34 \mathrm{E}-03$ & $1.76 \mathrm{E}-03$ & $2.36 \mathrm{E}-05$ & $1.36 \mathrm{E}-04$ & $3.86 \mathrm{E}-05$ & $2.00 \mathrm{E}-05$ \\
\hline PPM (2.5-10 $\mu \mathrm{m})$ & $\mathrm{kg} / \mathrm{kWh}$ & $7.61 \mathrm{E}-05$ & $7.48 \mathrm{E}-05$ & $1.23 \mathrm{E}-05$ & $1.20 \mathrm{E}-04$ & $4.86 \mathrm{E}-05$ & $3.22 \mathrm{E}-07$ & 4.73E-05 & $1.17 \mathrm{E}-05$ & $1.00 \mathrm{E}-05$ \\
\hline $\operatorname{PPM}(<2.5 \mu \mathrm{m})$ & $\mathrm{kg} / \mathrm{kWh}$ & $6.47 \mathrm{E}-05$ & 5.31E-05 & 8.22E-06 & $0.00 \mathrm{E}+00$ & 4.25E-05 & $0.00 \mathrm{E}+00$ & 2.37E-05 & $0.00 \mathrm{E}+00$ & $0.00 \mathrm{E}+00$ \\
\hline $\mathrm{SO}_{2}$ & $\mathrm{~kg} / \mathrm{kWh}$ & $1.69 \mathrm{E}-04$ & $6.18 \mathrm{E}-04$ & $1.47 \mathrm{E}-04$ & $6.16 \mathrm{E}-04$ & $5.31 \mathrm{E}-04$ & 8.99E-06 & $2.33 \mathrm{E}-04$ & $3.83 \mathrm{E}-05$ & $2.71 \mathrm{E}-03$ \\
\hline $\mathrm{CO}_{2}$ & $\mathrm{~kg} / \mathrm{kWh}$ & $9.21 \mathrm{E}-01$ & $7.76 \mathrm{E}-01$ & $3.98 \mathrm{E}-01$ & $6.74 \mathrm{E}-01$ & $1.80 \mathrm{E}-02$ & $2.51 \mathrm{E}-03$ & $5.52 \mathrm{E}-02$ & $9.56 \mathrm{E}-03$ & $1.31 \mathrm{E}-01$ \\
\hline
\end{tabular}

a (NEEDS. 2009)

${ }^{\mathrm{b}}$ (Pyrovolakis and Georgakellos. 2005)

${ }^{c}$ Own calculations and (Georgakellos. 2012)

d (Dones et al.. 2007)

e (Fritsche and Rausch. 2009) 
Table 3. Atmospheric emissions' life cycle external cost of the electricity generation technologies examined

\begin{tabular}{|c|c|c|c|c|c|c|c|}
\hline \multirow[b]{2}{*}{ Fuel/RES Type } & \multirow[b]{2}{*}{ Unit } & \multicolumn{5}{|c|}{ Impact type } & \multirow[b]{2}{*}{ Total } \\
\hline & & Health & Biodiversity & Crop Yield & $\begin{array}{l}\text { Material } \\
\text { Damage }\end{array}$ & $\begin{array}{l}\text { Climate } \\
\text { Change }\end{array}$ & \\
\hline Lignite & $€ / \mathrm{kWh}$ & 7.01E-03 & $7.25 \mathrm{E}-04$ & $2.40 \mathrm{E}-04$ & $9.62 \mathrm{E}-05$ & $6.45 \mathrm{E}-03$ & $1.45 \mathrm{E}-02$ \\
\hline Hard Coal & $€ / \mathrm{kWh}$ & $1.00 \mathrm{E}-02$ & 8.70E-04 & $2.52 \mathrm{E}-04$ & 2.17E-04 & $5.43 \mathrm{E}-03$ & 1.68E-02 \\
\hline Natural Gas & $€ / \mathrm{kWh}$ & $3.01 \mathrm{E}-03$ & $3.11 \mathrm{E}-04$ & $1.15 \mathrm{E}-04$ & $6.00 \mathrm{E}-05$ & $2.79 \mathrm{E}-03$ & $6.29 \mathrm{E}-03$ \\
\hline Oil & $€ / \mathrm{kWh}$ & $4.03 \mathrm{E}-02$ & $6.08 \mathrm{E}-03$ & $2.06 \mathrm{E}-03$ & $6.09 \mathrm{E}-04$ & $4.72 \mathrm{E}-03$ & 5.38E-02 \\
\hline Biomass & $€ / \mathrm{kWh}$ & $1.48 \mathrm{E}-02$ & $1.74 \mathrm{E}-03$ & 5.99E-04 & 2.62E-04 & $1.26 \mathrm{E}-04$ & $1.75 E-02$ \\
\hline Hydro & $€ / \mathrm{kWh}$ & $1.94 \mathrm{E}-04$ & $2.38 \mathrm{E}-05$ & $7.62 \mathrm{E}-06$ & $4.00 \mathrm{E}-06$ & $1.76 \mathrm{E}-05$ & 2.47E-04 \\
\hline PV & $€ / \mathrm{kWh}$ & 2.97E-03 & $1.66 \mathrm{E}-04$ & 4.92E-05 & $7.00 \mathrm{E}-05$ & $3.86 \mathrm{E}-04$ & $3.64 E-03$ \\
\hline Wind & $€ / \mathrm{kWh}$ & 4.87E-04 & $4.28 \mathrm{E}-05$ & $1.27 \mathrm{E}-05$ & $1.27 \mathrm{E}-05$ & $6.69 \mathrm{E}-05$ & 6.22E-04 \\
\hline Geothermal & $€ / \mathrm{kWh}$ & $1.73 \mathrm{E}-02$ & $5.17 \mathrm{E}-04$ & $-9.64 \mathrm{E}-05$ & 7.03E-04 & $9.14 \mathrm{E}-04$ & $1.94 E-02$ \\
\hline
\end{tabular}


Table 4. Notations

\begin{tabular}{|c|c|}
\hline Indices & Description \\
\hline$i$ & Technologies included in the study \\
\hline$t$ & Years $[2012,2050]$ \\
\hline Sets & Description \\
\hline REN & Renewable technologies \\
\hline CONV & Conventional technologies \\
\hline Parameters & Description \\
\hline$A I_{i, t}$ & Investment annuities (€/MWel/year) \\
\hline$C f_{i, t}$ & Fuel cost (€/MWh fuel) \\
\hline $\mathrm{Cco}_{t}$ & Forecasted $\mathrm{CO} 2$ price in year $\mathrm{t}(€ / \mathrm{tn} \mathrm{CO} 2)$ \\
\hline $\mathrm{CO}_{i, t}$ & Total emissions allowance cost for year $\mathrm{t}$ and conventional tech. i ( $€ / \mathrm{MWel})$ \\
\hline$E_{i}$ & Energy generated yearly from unitary capacity of technology i (MWh/MWel) \\
\hline Edem $_{t}$ & Energy demand in year $\mathrm{t}(\mathrm{MWh})$ \\
\hline$E G C_{i, t}$ & Average levelised lifetime electricity generation cost $(€ / \mathrm{MWh})$ \\
\hline $\operatorname{Emco}_{i}$ & $\mathrm{CO} 2$ emissions of technology i (tnCO2/MWh electr.) \\
\hline$E x t_{i}$ & Externality costs of technology i per year (€/MWel) \\
\hline$F_{i, t}$ & Total fuel cost for year $\mathrm{t}$ and technology i (€/MWel) \\
\hline$I_{i, t}$ & Investment cost per unit of capacity installed ( $€ / M W e l)$ \\
\hline$O M f_{i, t}$ & Fixed Operational \& Maintenance costs $(€ / \mathrm{kWel})$ \\
\hline$O M v_{i, t}$ & Variable Operational \& Maintenance costs (€/MWel) \\
\hline$P c l_{i, t}$ & Capacity of tech. i scheduled to be decommissioned in year $\mathrm{t}(\mathrm{MWel})$ \\
\hline Pdem $_{t}$ & Peak-load demand in year $\mathrm{t}(\mathrm{MWel})$ \\
\hline $\operatorname{Pmax}_{i}$ & Maximum resource potential of technology i (MWel) \\
\hline Ptot $_{i, t}$ & Installed capacity of technology $\mathrm{i}$ in year $\mathrm{t}(\mathrm{MWel})$ \\
\hline$Q_{i, t}$ & Projected global installed capacity of technology i in year $\mathrm{t}(\mathrm{GW})$ \\
\hline$T_{o p}$ & Operational lifetime of technology i (Years) \\
\hline$b_{i}$ & Learning rate of technology $i$ \\
\hline $\operatorname{fav}_{i}$ & Availability factor of technology i \\
\hline fcap $_{i}$ & Capacity factor of technology i \\
\hline$n_{i}$ & Efficiency factor of technology i \\
\hline$r$ & Interest rate \\
\hline
\end{tabular}


Table 5: Input data of the model ${ }^{\text {a }}$

\begin{tabular}{|c|c|c|c|c|c|c|c|c|c|c|}
\hline & 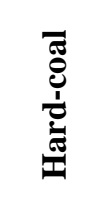 & $\bar{\sigma}$ & 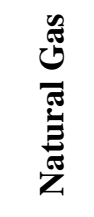 & 莺 & है & $\begin{array}{l}2 \\
\dot{\bar{m}} \\
\frac{1}{0}\end{array}$ & 㟒莺 & 弟 & 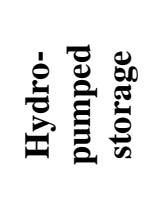 & 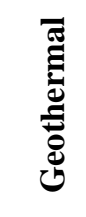 \\
\hline Investment cost $\left(€ / K W_{\mathrm{el}}\right)$ & 1295 & 1150 & 697 & 1050 & 2200 & 2222 & 1100 & 1300 & 3400 & 1800 \\
\hline Fixed cost $(O \& M$, insurance etc. $)\left(€ / \mathbf{k W}_{\mathrm{el}}\right)$ & 56.4 & 38 & 18.8 & 35 & 19 & 30 & 18 & 3 & 50 & 32 \\
\hline Variable cost $\left(€ / \mathbf{M W h}_{\mathrm{el}}\right)$ & 3.2 & 1.6 & 1.6 & 1 & 0 & 0 & 0 & 1.5 & 1.5 & 18 \\
\hline Availability factor & 0.9 & 0.85 & 0.75 & 0.9 & 0.85 & 0.99 & 0.98 & 0.98 & 0.92 & 0.7 \\
\hline Capacity factor & 0.85 & 0.8 & 0.85 & 0.85 & 0.85 & 0.17 & 0.27 & 0.25 & 0.4 & 0.9 \\
\hline Learning rate & 0.01 & 0.01 & 0.01 & 0.01 & 0.15 & 0.2 & 0.1 & 0 & 0 & 0 \\
\hline Efficiency Factor & 0.46 & 0.45 & 0.6 & 0.41 & 0.3 & 1 & 1 & 1 & 1 & 1 \\
\hline Financial Life-Time (Years) & 40 & 40 & 30 & 40 & 40 & 25 & 20 & 40 & 40 & 40 \\
\hline
\end{tabular}

a (Caralis et al., 2008; IEA, 2005; IEA, 2010; Kumbaroglu et al., 2008) 
Table 6: Estimated fuel price evolution ( $€ / M W h)$

\begin{tabular}{lccccc}
\hline & Hard-coal & Oil & Natural Gas & Lignite & Biomass \\
& & & & & \\
\hline $\mathbf{2 0 1 2}$ & 6.55 & 30.78 & 16.34 & 3.74 & 5.96 \\
$\mathbf{2 0 2 0}$ & 6.84 & 44.85 & 18.36 & 4.32 & 6.51 \\
$\mathbf{2 0 3 0}$ & 7.56 & 50.24 & 20.88 & 5.04 & 7.27 \\
$\mathbf{2 0 4 0}$ & 8.28 & 55.90 & 23.76 & 5.40 & 8.10 \\
$\mathbf{2 0 5 0}$ & 9.00 & 62.20 & 26.28 & 6.12 & 9.04 \\
\hline
\end{tabular}

